\title{
Temperature Variability and Trends in Nzoia River Basin, Kenya
}

\author{
Ernest Othieno Odwori ${ }^{a^{*}}$ \\ ${ }^{a}$ Department of Disaster Management and Sustainable Development, School of Disaster \\ Management and Humanitarian Assistance, Masinde Muliro University of Science and Technology, \\ P.O. Box 190-50100, Kakamega, Kenya.
}

Author's contribution

The sole author designed, analysed, interpreted and prepared the manuscript.

Article Information

DOI: $10.9734 / A J G R / 2021 / v 4 i 4100$ Editor(s):

(1) Dr. Xu Chong, Institute of Geology, China.

Reviewers:

(1) Szabó-Takács Beáta, Global Change Research Institute, Czech Republic.

(2) Derling Mendoza, Ecuador.

(3) Catine Chimene, Eduardo Mondlane University, Mozambique. Complete Peer review History, details of the editor(s), Reviewers and additional Reviewers are available here: https://www.sdiarticle5.com/review-history/77403

Original Research Article

Received 01 October 2021 Accepted 02 December 2021 Published 16 December 2021

\section{ABSTRACT}

Nzoia River Basin is one of the regions that is highly vulnerable to climate change in Kenya. Many attempts have been made to identify and quantify the impact of climate change on socio-economic sectors and ecosystems using global studies resulting into recommendations on policy changes aimed at generating sustainable mitigation and adaptation strategies. This top-down approach by using global studies lacks the required local and regional climate change specificities to address the regional and local climate change challenges. Temperature is one of the most important components of the climatic parameters widely measured as a starting point towards the apprehension of climate change courses. This study aims at filling the top-down approach knowledge gaps in Nzoia River Basin by assessing temperature variability and trends at three stations for the period 1979 to 2014, using Linear regression analysis and Mann-Kendall statistical test. Monthly maximum and minimum temperature data for Kitale, Kakamega and Eldoret stations was obtained from Kenya Meteorological Department, Nairobi, Kenya. The main findings reveal that Kakamega has highest temperatures, followed by Kitale and the lowest temperatures are found at Eldoret. This trend seems to go with altitude as the lowest temperatures are found at highest altitudes and highest temperatures at lowest altitudes. There are significant increases in annual temperatures for Kitale and Kakamega stations, with Kitale showing annual maximum 
temprature rising at $0.000626^{\circ} \mathrm{C} /$ year; annual minimum temperature rising at $0.001163^{\circ} \mathrm{C} /$ year and the annual mean temprature rising at $0.000894^{\circ} \mathrm{C} /$ year. Kakamega shows annual maximum temperature rising at $0.000771^{\circ} \mathrm{C} /$ year; annual minimum temperatures rising at $0.000471^{\circ} \mathrm{C} / \mathrm{year}$ and the annual mean temperatures rising at $0.000623^{\circ} \mathrm{C} /$ year. Eldoret shows falling maximum temperature at $-0.00202^{0} \mathrm{C} /$ year; rising minimum temperature at $0.000813^{0} \mathrm{C} / \mathrm{year}$ and falling mean temperatures at $-0.00142^{\circ} \mathrm{C} /$ year. The results for Kitale and Eldoret stations show statistically significant trends whereas those for Kakamega station were statistically insignificant. Eldoret annual minimum temperatures are rising faster than the maximum whereas in Kakamega it's the annual maximum temperatures that are rising faster than the minimum. Kitale and Kakamega show annual mean temperatures rising at about $0.1^{\circ} \mathrm{C}$ per century which compares well with IPCC Third Assessment Report estimated global warming rate of $0.6^{\circ} \mathrm{C}$ during the twentieth century and other studies from the African continent and East African region.

Keywords: Nzoia River Basin; temperature; variability and trends; linear regression analysis; mannkendall statistical test.

\section{INTRODUCTION}

Climate change has been a major concern for scientists all around the world since the inaugural World Climate Conference, held in Geneva from 12th to 23rd of February 1979 and sponsored by the World Meteorological Organization. Because of its capacity to depict the energy exchange process over the earth's surface with fair accuracy, air temperature is widely regarded as a good predictor of the status of the climate globally [1]. Temperature is the second most important meteorological variable after precipitation because it is linked to solar radiation and hence to evaporation and transpiration processes, both of which are key phases of the hydrologic cycle. Several scientists, as well as the Intergovernmental Panel on Climate Change (IPCC), concur that the Earth's surface has warmed significantly during the previous century. The Earth's warming over the twentieth century resulted in a decrease in the region of the world impacted by extremely cold temperatures and, to a lesser extent, an increase in the area affected by extremely warm temperatures [2].

Some studies of extended temperature time series on a hemispheric and global scale have found a warming rate of $0.3-0.6^{\circ} \mathrm{C}$ since the midnineteenth century, attributed to either human or astronomic causes. According to the Third Assessment Report, average temperature rises by 2100 will range between 1.4 and 5.8 degrees Celsius [3]. Global temperatures rose to $0.6 \pm$ $0.2^{\circ} \mathrm{C}$ on average over land and sea throughout the twentieth century, according to records. A number of recent studies have focused on longterm temperature fluctuations on a global, hemispheric, or regional scale. On a global basis, climatological studies show a $0.3-0.6^{\circ} \mathrm{C}$ increase in surface air temperature since 1860 , with 0.5 $0.7^{\circ} \mathrm{C}$ for the Northern Hemisphere.

Many experts have highlighted that the warming has not been consistent throughout the day, with lower warming at maximum temperatures and significantly higher warming in minimum temperatures. According to Karl and Easterling [4], worldwide daytime and daily mean temperatures increased by $0.28^{\circ} \mathrm{C}$ between 1951 and 1990, but nighttime temperature (daily minimum) increased three times as much by $0.84^{\circ} \mathrm{C}$. In other words, the daily minimum temperature is warming faster than the maximum temperature. In recent years, a growing number of studies have looked at the variability and tendencies of extreme temperature events across various regions of the world, taking into account that extremes at regional scales have larger amplitudes than extremes at the global scale, and the importance of regional climate change studies in evaluating climate change impacts. Various analyses of daily minimum, maximum, and extreme temperatures were conducted over North America [5], Canada [6], Europe [7], Australia and New Zealand [8], Eastern Africa [9], India [10], and South Korea $[10,11]$.

Beniston et al. [12] emphasized the importance and challenges of studying climate change in high-elevation areas, whereas Diaz et al. [13] acknowledged the complexities of climate research in mountainous areas. Mountainous locations, according to Messerli and Ives [14], are more sensitive and vulnerable to climate change than other places at similar latitudes on Earth. As a result, it is reasonable to conclude that global climate change should be detectable at an early stage by examining trends in climate 
variability and the occurrence of extreme events in mountainous areas. The warming trend in the European Alps, for example, was larger than the world mean warming trend during the twentieth century [12]. Furthermore, while comparing the trends in maximum and minimum temperatures, it was shown that high-elevation locations in the Alps warmed more than low-lying sites [15].

According to Nicholls and Collins [16], the average maximum temperature in Australia climbed by 0.6 degrees Celsius from 1910 to 2004, and the average minimum temperature increased by 1.2 degrees Celsius from 1950 to 2004. In Europe, the growing trend in monthly and seasonal surface temperature is warmer in the late 20th and early 21 st centuries than at any time in the previous 500 years [17]. Annual mean air temperature in North America increased from 1955 to 2005, with Alaska and northeastern Canada experiencing the most warming. Over the last 53 years, the yearly mean temperature in Canada has risen by 1.2 degrees Celsius [18].

In Asia, rising patterns have been noted in each of Asia's seven subregions [19]; 2 to 3 degrees Celsius in Russia [20]; 1.8 degrees Celsius in Mongolia [21]; 0.7 degrees Celsius in Northwest China [22]; 1.0 degrees Celsius in Japan [23]; 0.23 degrees Celsius in Korea [24]; and 0.14 degrees Celsius in the Philippines [25].

The annual mean, maximum, and minimum temperatures all show an upward trend in India [26-30]. Few study investigations have been completed separately on various cities in India [31,32] and identified the maximum, minimum and mean temperatures with mixed trends.

Increased concentrations of anthropogenic greenhouse gases [33-36], increased emissions of anthropogenic aerosols [37,38], increased cloud cover, and urbanization have all been linked to rising air temperatures, according to various research studies [39,40]. Furthermore, according to IPCC [19], the majority of the observed increase in average temperature since the mid-twentieth century is highly likely due to anthropogenic greenhouse gas concentrations.

Africa is one of the most vulnerable continents to climate change and variability, a condition made worse by the interaction of several pressures at various levels, as well as a lack of adaptation capacity [19]. The continent of Africa is now warmer than it was 100 years ago [41]. According to Niang et al. [42], the mean annual temperature over the majority of the African continent has likely increased during the 1900s. According to Hulme et al. [41], Africa has warmed at a pace of around $0.5^{\circ} \mathrm{C}$ per century since the 1900s, however Hussein [43] claims that Africa warmed at a rate of $0.7^{\circ} \mathrm{C}$ during the same time period. Minimum temperatures, on average, are rising at a faster rate than maximum temperatures (Niang et al. [42]. Anyah and Qiu [44] indicate considerable temperature rises in the equatorial and southern areas of East Africa since the 1980s. Climate and weather variability are expected to become more variable as the world warms. Changes in the frequency and severity of extreme climate events, as well as weather pattern variability, will have substantial implications for human and environmental systems. Since the early 1980 s, the equatorial and southern areas of eastern Africa have undergone a major rise in temperature [44]. In Ethiopia, Kenya, South Sudan, and Uganda, recent statistics from the Famine Early Warning Systems Network (FEWS NET) show that seasonal mean temperatures have risen in several locations during the previous 50 years [45].

As global warming continues to raise the average temperatures of the earth, it has become increasingly important to put mitigation and adaptation measures in place to manage and reduce the risks of the changing tempratures on productive systems in an effort to reduce the vulnerability of socio-economic sectors and ecological systems. A major problem faced in developing countries like Kenya and more specifically Nzoia River Basin is the availability of data to be used in tackling climate change induced challenges. Various stakeholders at regional, national and local levels are now engaging a number of strategies to mitigate the effects of climate change, but this may not yield good results if the variability and trends of the climatic variables such as temperature is not known. In studies on climate change detection, analyzing long-term changes in climatic variables is a critical challenge. Improvements and extensions of multiple datasets, as well as more advanced data analytics, have all contributed to a better knowledge of past and present climate change around the world [46]. Understanding the spatio-temporal dynamics of meteorological variables in the context of a changing climate, particularly in regions like Nzoia River Basin is vital to assess climate-induced changes and suggest feasible adaptation strategies. Understanding the uncertainties associated with temperature patterns will provide a knowledge 
base for better management of agriculture, irrigation, domestic water supply and other waterrelated activities in the basin. The investigation of long-term variations and trends in temperature data within Nzoia River Basin has not received enough attention even though the basin is suffering from serious environmental, agricultural and water resources management problems. In this study an attempt has been made to investigate variability and trends in maximum, minimum and mean tempratures within the basin.

\section{MATERIALS AND METHODS}

\subsection{Study Area}

Nzoia River Basin is located between latitudes $1^{0}$ $30^{\prime} \mathrm{N}$ and $0^{\circ} 05^{\prime} \mathrm{S}$ and longitudes $34^{\circ} \mathrm{E}$ and $35^{\circ}$ $45^{\prime} \mathrm{E}$ in Western Kenya and covers an area of $12,959 \mathrm{~km}^{2}$ with a river length of $334 \mathrm{~km}$ up to its outfall into Lake Victoria (Fig. 1). The area has a population of approximately 3.7 million people that is rising rapidly with the majority of the people living in rural areas. The basin covers the nine counties of Elgeyo/Marakwet, West Pokot, Trans Nzoia, Uasin Gishu and Nandi (in former Rift Valley province); Kakamega, Bungoma and Busia (in former Western province) and Siaya (in former Nyanza province). The basin is characterised by three physiographic regions namely; the highlands (characterised by Mt. Elgon and Cherangani hills); the upper plateau (which includes Eldoret and Kitale); and the lowlands (which includes Busia that experiences the majority of flooding in the basin).The dominant topography consists of rolling hills and lowlands in the Eldoret and Kitale plains. Nzoia river is one of the largest rivers in Western Kenya which drains into Lake Victoria contributing to the waters that form the source of River Nile.

The Climate of Nzoia River Basin is predominantly tropical humid, but it varies from county to county due to varying landscape and elevations in the basin. Due to the Inter-Tropical Convergence Zone (ITCZ), the region observes four seasons; however, the local relief and effects of Lake Victoria alter the typical weather patterns. There are two rainy seasons: short rains (October to December) and long rains (March to May). The months of January to February and June to September are the dry seasons [47].

The basin experiences lowest monthly maximum temperatures occuring in July at $16.1^{\circ} \mathrm{C}$ (Eldoret), minimum temperatures in January, July and September at $10.0^{\circ} \mathrm{C}$ (Eldoret) and mean temperatures in July at $16.1^{\circ} \mathrm{C}$ (Eldoret) whereas the highest monthly temperatures in the basin for the maximum occurs in February and March at $29.5^{\circ} \mathrm{C}$ (Kakamega), minimum in April at $15.1^{\circ} \mathrm{C}$ (Kakamega) and mean in March at $22.0^{\circ} \mathrm{C}$ (Kakamega). Temperature trends in the basin are linked to altitude since the lowest temperatures are found at highest altitudes and highest temperatures at lowest altitudes. Agriculture is the dominant land use in the region and the agricultural activities of the basin mainly depend on rainfall as most of the crops are under rain-fed agriculture with very limited irrigation being practiced. The main food crops grown are maize, sorghum, millet, bananas, groundnuts, beans, potatoes, and cassava while the cash crops include coffee, sugar cane, tea, wheat, rice, sunflower and horticultural crops. The inhabitants of the basin also practice dairy farming together with traditional livestock keeping. Nzoia river and its many tributaries provide water for domestic use, agriculture, industrial and commercial sectors [48].

\subsection{Data Sources}

Monthly maximum and minimum temperature data was collected for three stations; Kitale and Kakamega meteorological stations with data covering 35 years period from 1979 to 2014 and Eldoret international airport, 15 years period from 1999 to 2014 from the Kenya Meteorological Department (KMD), Nairobi, Kenya as shown in Table.1. Temperature data are expressed in degree Celsius $\left({ }^{0} \mathrm{C}\right)$. The weather stations were chosen based on their quality, the length and duration of time they covered, and whether or not they had simultaneous records of meteorological data. Monthly temperatures for each of the stations were calculated by averaging daily measurements. The annual mean temperature was calculated by averaging the monthly temperatures for each year. Roman et al. [49] provide additional information on measurement uncertainty. Before the data was used, several mandatory data quality control checks were done. All variables were compared to empirical upper and lower limits, as well as systematic errors from other sources (e.g., archiving, transcription and digitalization).

This can contain things like dates that don't exist. El Kenawy et al. [50]; Bilbao et al. [51]; Miguel et al. [52] and Roman et al. [49] provide more information on these tests. Instrumentation and alteration of surrounding land cover might create non-homogeneity and/or inconsistencies in meteorological data recording [53]. 


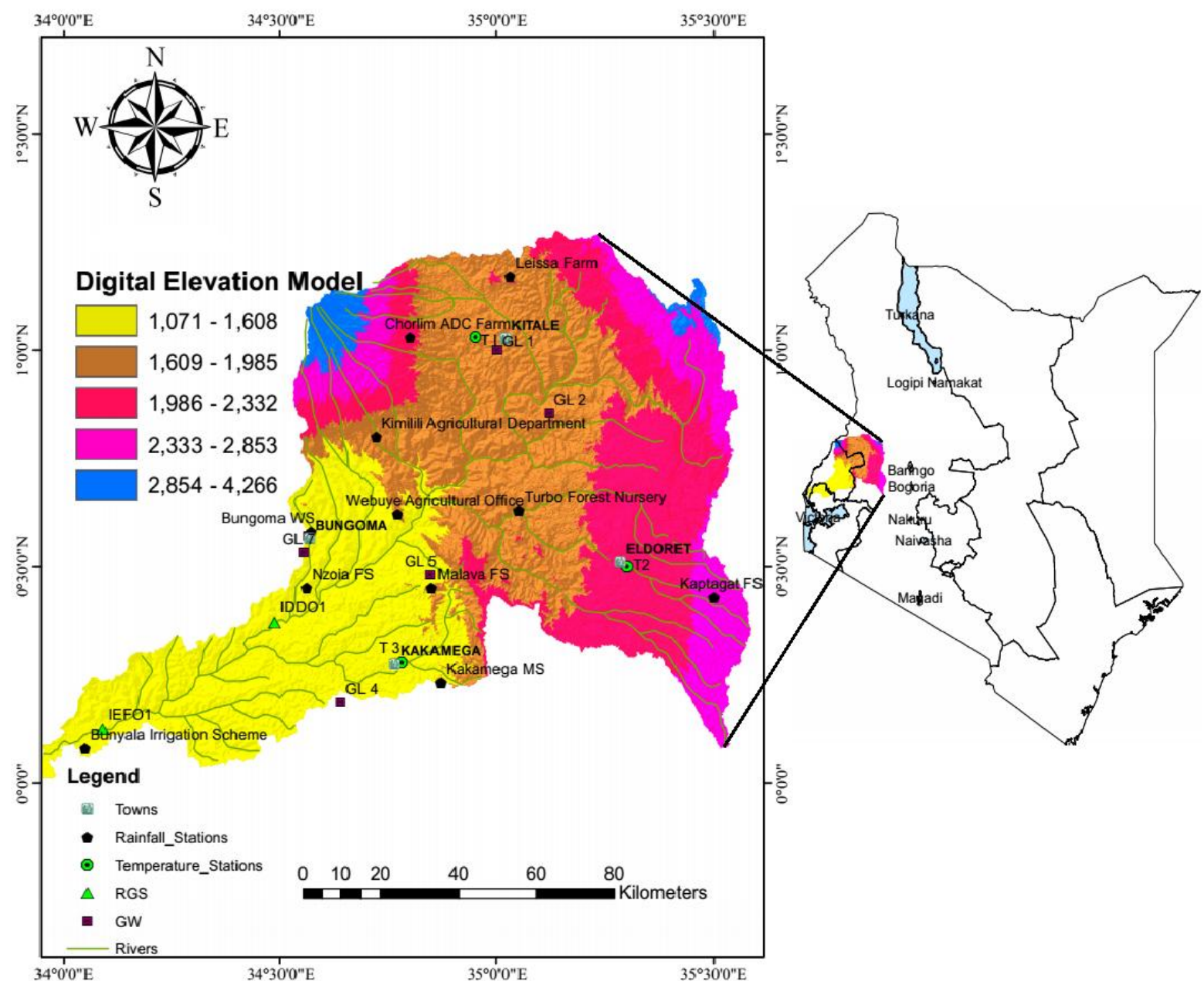

Fig. 1. Map of Nzoia River Basin, Kenya

Table 1. Temperature stations selected for study within Nzoia River Basin, Kenya

\begin{tabular}{llllll}
\hline $\begin{array}{l}\text { Station ID } \\
\text { (in Fig. 1) }\end{array}$ & $\begin{array}{l}\text { Station Wmo } \\
\text { Code }\end{array}$ & Station name & $\begin{array}{l}\text { Latitude } \\
\left({ }^{0} \mathrm{~N}\right)\end{array}$ & $\begin{array}{l}\text { Longitude } \\
\left({ }^{0} \mathrm{E}\right)\end{array}$ & $\begin{array}{l}\text { Altitude } \\
\text { (m.a.s.I) }\end{array}$ \\
\hline T I & 8834098 & $\begin{array}{l}\text { Kitale Meterological } \\
\text { Station }\end{array}$ & 1.03 & 34.95 & 1825 \\
T2 & 8935115 & $\begin{array}{l}\text { Eldoret International } \\
\text { Airport }\end{array}$ & 0.50 & 35.30 & 2120 \\
T 3 & 8934096 & $\begin{array}{l}\text { Kakamega } \\
\text { Meteorological Station }\end{array}$ & 0.28 & 34.78 & 1501 \\
\hline
\end{tabular}

\subsection{Methodology}

Trend analysis of a time series consists of the magnitude of trend and its statistical significance. Different scholars have used different methodologies for trend detection. Kundzewicz [54] has discussed the change detection methodologies for hydrologic data. Sen [55] posits that, "in general, the magnitude of trend in a time series is determined either using regression analysis (parametric test) or using
Sen's estimator method (non-parametric method)". Both methods assume that the time series has a linear trend.

\subsubsection{Regression analysis}

Regression analysis is conducted with time as the independent variable and temperature as the dependent variable. The regression analysis is carried out directly on the time series or on the anomalies (i.e. deviation from mean). A linear 
equation, $\mathrm{y}=\mathrm{mt}+\mathrm{c}$, defined by $\mathrm{c}$ (the intercept) and trend $\mathrm{m}$ (the slope), is fitted by regression. The linear trend value represented by the slope of the simple least-square regression line provides the rate of rise or fall in the temprature.

\subsubsection{Sen's slope estimator test}

The Mann Kendall test does not provide an estimate of the magnitude of the trend, hence for this purpose, different statistical estimators have been used over the world to study the climatological time series, eg. temperature. The magnitude of a trend in a time series can be determined using a non-parametric method known as Sen's estimator (Sen, 1968). To estimate the true slope of an existing trend such as the amount of change per year, Sen's nonparametric method is used. Sen's Slope method involves computing slopes for all the pairs of ordinal time points and then using the median of these slopes as an estimate of the overall slope. The Sen's method assumes that the trend is linear.

Fan and Yao [56] observes that, "this approach provides a more robust slope estimate than the least-squares method because it is insensitive to outliers or extreme values and competes well against simple least squares even for normally distributed data in the time series". The climate variability study of data series and its analysis requires trends and their statistical significance to be evaluated. Trend evaluations in seasonal and annual temperatures (maximum, minimum and mean) can be performed using the Theil-Sen (TTS) estimator and its 95\% ( $\alpha=0.05)$ confidence interval $(95 \mathrm{Cl})$. This estimator can be calculated following the methods proposed by $[57,58]$. The results provide the most suitable trend values due to the sensitivity of the method to extreme data, [59]. Similar tests have also been used by Sayemuzzaman et al. [59]; Roman et al. [49]; Espadafor et al. [60]; Gocic and Trajkovic [53].

\subsubsection{The mann-kendall non-parametric trend test of significance}

The Mann Kendall test $[61,62]$ is a statistical test widely used for trend analysis in climatological and hydrological time series [63]. This is a rank based method which is non-parametric and is based on an alternative measure of correlation called Kendall's т. The Mann-Kendall tests are based on the calculation of Kendall's tau measure of association between two samples, which is itself based on the ranks with the samples. The statistic $T$ is defined as the difference between the probabilities of concordance and discordance between the two variables. Mann [61] originally used MK test and Kendall [62] subsequently derived the test statistic distribution. The Mann-Kendall statistical test is frequently used to quantify the significance of trends in meteorological time series. The advantage of the method is that normal distribution of data is not expected. The result is seldom influenced by the fewer abnormal values and calculation is simple. There are two advantages of using this test. First, it is a nonparametric test and does not require data to be normally distributed. Second, the test has low sensitivity to abrupt breaks due to inhomogeneous time series [64]. Any data reported as non-detects are included by assigning them a common value that is smaller than the smallest measured value in the data set.

A score of +1 is awarded if the value in a time series is larger, or a score of -1 is awarded if it is reduced. The overall score for the time-series data is the Mann-Kendall statistic which is then compared to a critical value to test whether the trend in temperature is increasing, decreasing or if no trend can be observed. The strength of the trend is proportional to the magnitude of the Mann-Kendall Statistic. Sgn $(X j-X k)$ is an indicator function that results in the values 1,0 , or -1 according to the significance of $\mathrm{Xj}-\mathrm{Xk}$ where $\mathrm{j}>\mathrm{k}$, the function is calculated as follows:

$$
\begin{aligned}
& \operatorname{sgn}(X j-X k)=1 \rightarrow \text { if }, X j-X k>0 \\
& \operatorname{sgn}(X j-X k)=0 \rightarrow \text { if }, X j-X k=0 \\
& \operatorname{sgn}(X j-X k)=-1 \rightarrow \text { if }, X j-X k<0
\end{aligned}
$$

where $\mathrm{Xj}$ and $\mathrm{Xk}$ are the sequential temperature values in months $\mathrm{J}$ and $\mathrm{K}(\mathrm{J}>\mathrm{k})$ respectively; whereas, a positive value is an indicator of increasing (upward) trend and a negative value is an indicator of decreasing (downward) trend.

In the equation, $X 1, X 2, X 3, \ldots, X n$ represents ' $n$ ' data points (monthly), where $\mathrm{Xj}$ represents the data point at time $\mathrm{J}$. Then the Mann-Kendall statistics $(S)$ is defined as the sum of the number of positive differences minus the number of negative differences, given by:

$$
\mathrm{S}=\sum_{k=1}^{n-1} \sum_{j=k+1}^{n} \operatorname{sgn}=(x j-x k)
$$

where 


$$
\begin{aligned}
& \operatorname{sgn}(X j-X k)=1 \rightarrow \text { if }, X j-X k>0 \\
& \operatorname{sgn}(X j-X k)=0 \rightarrow \text { if }, X j-X k=0 \\
& \operatorname{sgn}(X j-X k)=-1 \rightarrow \text { if }, X j-X k<0
\end{aligned}
$$

Trends considered at the study sites were tested for significance. A normalized test statistic (Zscore) is used to check the statistical significance of the increasing or decreasing trend of mean temperature values. The trends of temperature are determined and their statistical significance is tested using Mann-Kendall trend significant test with the level of significance $0.05\left(Z_{-} \alpha / 2= \pm\right.$ 1.96).

$$
\begin{aligned}
& Z=\frac{\mathrm{n}-1}{\sqrt{\operatorname{Var}(\mathrm{S})}} \rightarrow \text { if } \mathrm{S}>0 \\
& Z=0 \rightarrow \text { if }, \mathrm{S}=0 \\
& Z=\frac{\mathrm{n}-1}{\sqrt{\operatorname{Var}(\mathrm{S})}} \rightarrow \text { if } \mathrm{S}<0
\end{aligned}
$$

Hypothesis testing Ho $=\mu=\mu$ o (there is no significant trend/stable trend in the data).

$\mathrm{Ha}=\mu_{-} \mu_{\mathrm{o}}$ (there is a significant trend/unstable trend in the data) If $-Z_{1-\alpha / 2} \leq Z \leq Z_{1-\alpha / 2}$ accepts the hypothesis or else reject the null hypothesis. Powerfully increasing or decreasing trends indicate a higher level of statistical significance [65].

\section{RESULTS AND DISCUSSION}

\subsection{Temperature Trend at Kitale Meteorological Station}

The monthly mean maximum temperatures at Kitale meteorological station in the period 1979 to 2014 shows a gradually declining trend from February to July. Beginning with January at 28.3 ${ }^{0} \mathrm{C}$, the maximum temperature rises to $28.6^{\circ} \mathrm{C}$ in February (hottest month of the year) and then falls gradually to $23.9^{\circ} \mathrm{C}$ in July (coldest month of the year), followed by a gradual rise reaching $26.3^{6} \mathrm{C}$ in December to repeat the annual cycle again. The monthly mean maximum tempratures for Kitale meteorological station in the period 1979 to 2014 has been gradually decreasing from January to December. The annual mean maximum temperatures at Kitale meteorological station have gradually increased from 1979 to 2014 at the rate of $0.000626{ }^{\circ} \mathrm{C} /$ year. The lowest mean maximum temperature of $25.1^{\circ} \mathrm{C}$ was recorded in 1989 (coldest year in the period). The highest mean maximum temperature of $25.9^{\circ} \mathrm{C}$ was recorded in 1980 (hottest year in the period).

Monthly mean minimum temperatures for the station in the period 1979 to 2014 depict a slowly decreasing trend from January to December. Beginning from January with $10.7^{\circ} \mathrm{C}$ (lowest temperature recorded in the year within the period), the temperature rises to $13.3^{\circ} \mathrm{C}$ in April (highest temperature recorded in the year within the period) and then falls gradually to $10.9^{\circ} \mathrm{C}$ in December to repeat the annual cycle. Annual mean minimum temperatures for Kitale meteorological station in the period 1979 to 2014 has been rising at $0.001163^{\circ} \mathrm{C} /$ year. Lowest mean minimum temperatures in the period were recorded at $10.5^{\circ} \mathrm{C}$ in 1976 and the highest temperature ever recorded in the period was at $12.6^{\circ} \mathrm{C}$ in 1998 . The monthly mean temperatures for Kitale meteorological station in the period 1979 to 2014 depicts a decreasing trend from January to December. Beginning from January with $19.1^{\circ} \mathrm{C}$, the temperature rises to $20.3^{\circ} \mathrm{C}$ in March (highest temperature recorded in the year within the period) and then falls gradually to $17.9^{\circ} \mathrm{C}$ in July (lowest temperature recorded in the year within the period), followed by a gradual rise to $18.8^{\circ} \mathrm{C}$ in October and a fall to $18.6^{\circ} \mathrm{C}$ in December to repeat the annual cycle.

The Annual mean temperatures for Kitale meteorological station has been increasing at the rate of $0.000894^{\circ} \mathrm{C} /$ year. Lowest mean temperatures in the period were recorded at $10.5^{\circ} \mathrm{C}$ in 1975 and the highest temperature ever recorded in the period was at $15.6^{\circ} \mathrm{C}$ in 2013. The results in Fig. 2 shows that based on the standard seasons of December-JanuaryFebruary (DJF), March-April-May (MAM), JuneJuly August (JJA) and September- OctoberNovember (SON) in Nzoia River Basin, there has been small fluctuations in monthly minimum, maximum and mean temperatures for the period between 1979 and 2014.

\subsection{Temperature Trend at Eldoret International Airport}

The monthly mean maximum temperatures for Eldoret international airport in the period 1999 to 2014 depicts a declining trend from January to December. The monthly mean maximum temperatures beginning with January at $16.8^{\circ} \mathrm{C}$, rises to $18.4^{\circ} \mathrm{C}$ in March (hotest month of the year) and then falls gradually to $16.1^{\circ} \mathrm{C}$ in July (coldest month of the year), followed by a gradual rise to $17.5^{\circ} \mathrm{C}$ in October and a fall to 
$17.0^{\circ} \mathrm{C}$ in December to repeat the annual cycle. Annual mean maximum temperatures for Eldoret international airport in the period 1999 to 2014 depict a declining trend at the rate of $0.00202^{\circ} \mathrm{C} /$ year. There was a drastic fall in temperatures between 2005 and 2008 reaching the lowest tempratures ever experienced in the period at $23.02^{\circ} \mathrm{C}$. This was followed by a steady rise in tempratures between 2008 and 2009 reaching $24.93^{\circ} \mathrm{C}$ which is the highest temperature ever recorded in the period. Thereafter, a gradual fall continued until 2013. The monthly mean minimum temperatures for Eldoret international airport in the period 1999 to 2014 depict a rising trend from January to December. Beginning from January with $8.6^{\circ} \mathrm{C}$, the temperature rises to $11.6^{\circ} \mathrm{C}$ in April (highest temperature recorded in the year within the period) and then falls gradually to about $10.0^{\circ} \mathrm{C}$ in July and September (lowest temperatures recorded in the year within the period), followed by a gradual rise to $10.7^{\circ} \mathrm{C}$ in November and a fall to $9.7^{\circ} \mathrm{C}$ in December to repeat the annual cycle.

The Annual mean minimum temperatures for Eldoret international airport in the period 1999 to 2014 depict a slowly rising trend at the rate of $0.000813^{\circ} \mathrm{C}$ /year. A gradual rise in temperatures was noted between 2000 and 2006 reaching the highest temperatures ever experienced in the period of $11.08^{\circ} \mathrm{C}$. This was followed by a steady fall in temperatures between 2006 and 2009 reaching $7.42^{\circ} \mathrm{C}$ which is the lowest temperature ever recorded in the period. The monthly mean temperatures for Eldoret international airport in the period 1999 to 2014 depict a declining trend from January to December. Beginning from January with $16.8^{\circ} \mathrm{C}$, the temperature rises steadly to $18.4^{\circ} \mathrm{C}$ in March (highest temperature recorded in the year within the period) and then falls gradually to $16.1^{\circ} \mathrm{C}$ in July (lowest temperature recorded in the year within the period), followed by a gradual rise to $17.4^{\circ} \mathrm{C}$ in October and a fall to $17.0^{\circ} \mathrm{C}$ in December to repeat the annual cycle.

The Annual mean temperatures for Eldoret international airport in the period 1999 to 2014 depict a slowly declining trend at the rate of $0.00142^{\circ} \mathrm{C}$ /year. A slow rise in temperatures was noted between 1999 and 2005 reaching the highest temperatures ever experienced in the period of $17.66^{\circ} \mathrm{C}$. This was followed by a steady fall in temperatures between 2006 and 2008 reaching $16.41^{\circ} \mathrm{C}$ which is the lowest temperature ever recorded in the period. The results in Fig. 3 shows that based on the standard seasons of December-JanuaryFebruary (DJF), March-April-May (MAM), JuneJuly August (JJA) and September- OctoberNovember (SON) in Nzoia River Basin, there has been fluctuations in monthly minimum, maximum and mean temperatures for the period between 1999 and 2014.

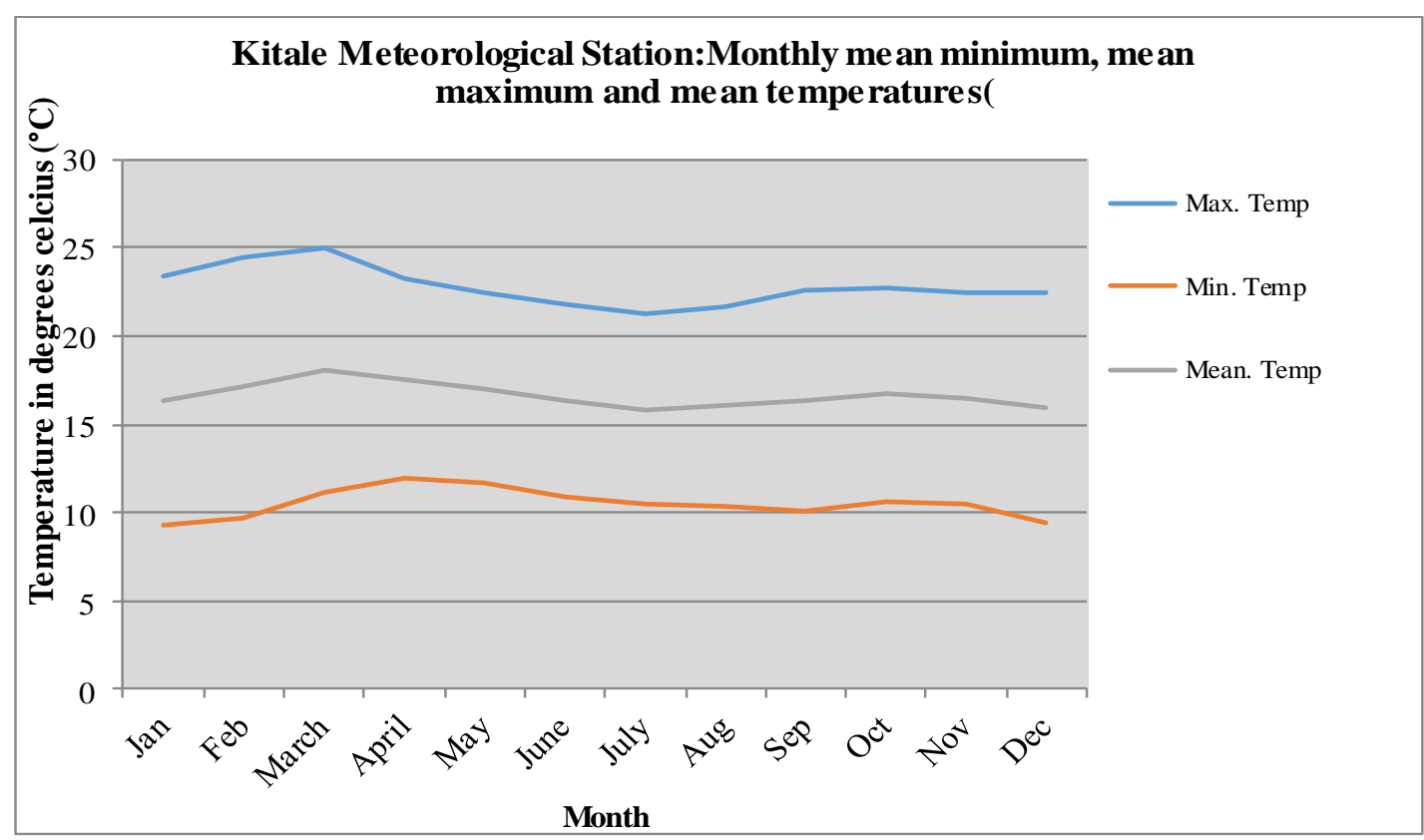

Fig. 2. Comparison of monthly mean minimum, mean maximum and mean temperatures for Kitale meteorological station between 1979 and 2014 


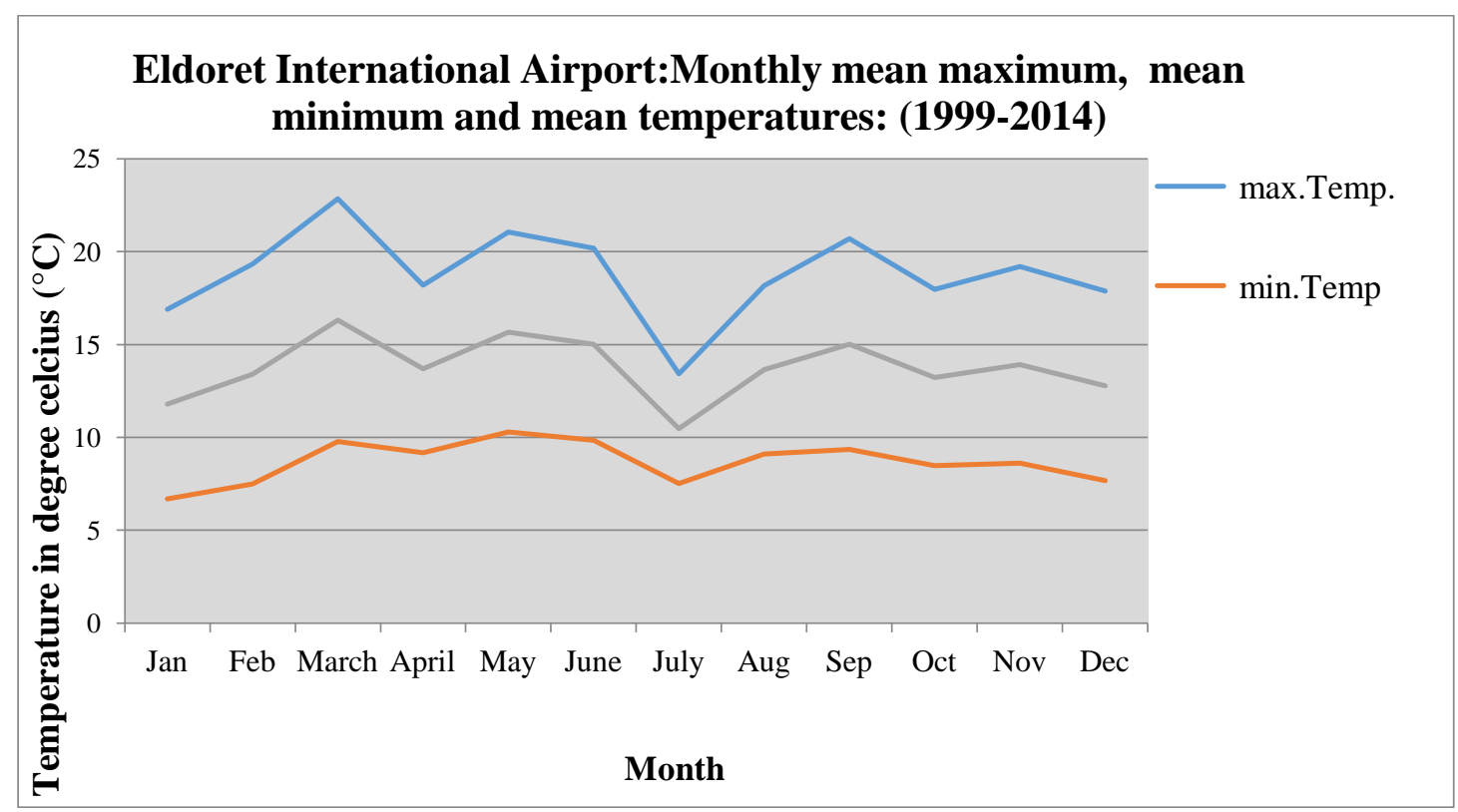

Fig. 3. Comparison of monthly mean minimum, mean maximum and mean temperatures for Eldoret international airport between 1999 and 2014

\subsection{Temperature Trend at Kakamega Meteorological Station}

The monthly mean maximum temperatures for Kakamega meteorological station in the period 1979 to 2014 depicts a declining trend from January to December. Beginning from January at $28.7^{\circ} \mathrm{C}$, the temperature rises to $29.5^{\circ} \mathrm{C}$ in February (hottest month of the year) and then falls gradually to $25.8^{\circ} \mathrm{C}$ in July (coldest month of the year), followed by a gradual rise reaching $27.8^{\circ} \mathrm{C}$ in December to repeat the annual cycle again. The Annual mean maximum temperatures for Kakamega meteorological station in the period 1979 to 2014 depict a rising trend at the rate of $0.000771^{0}$ C/year. Lowest mean maximum temperatures in the period were recorded at $26.7^{\circ} \mathrm{C}$ in 1989 and the highest temperature ever recorded in the period was at $28.3^{0} \mathrm{C}$ in 2009.

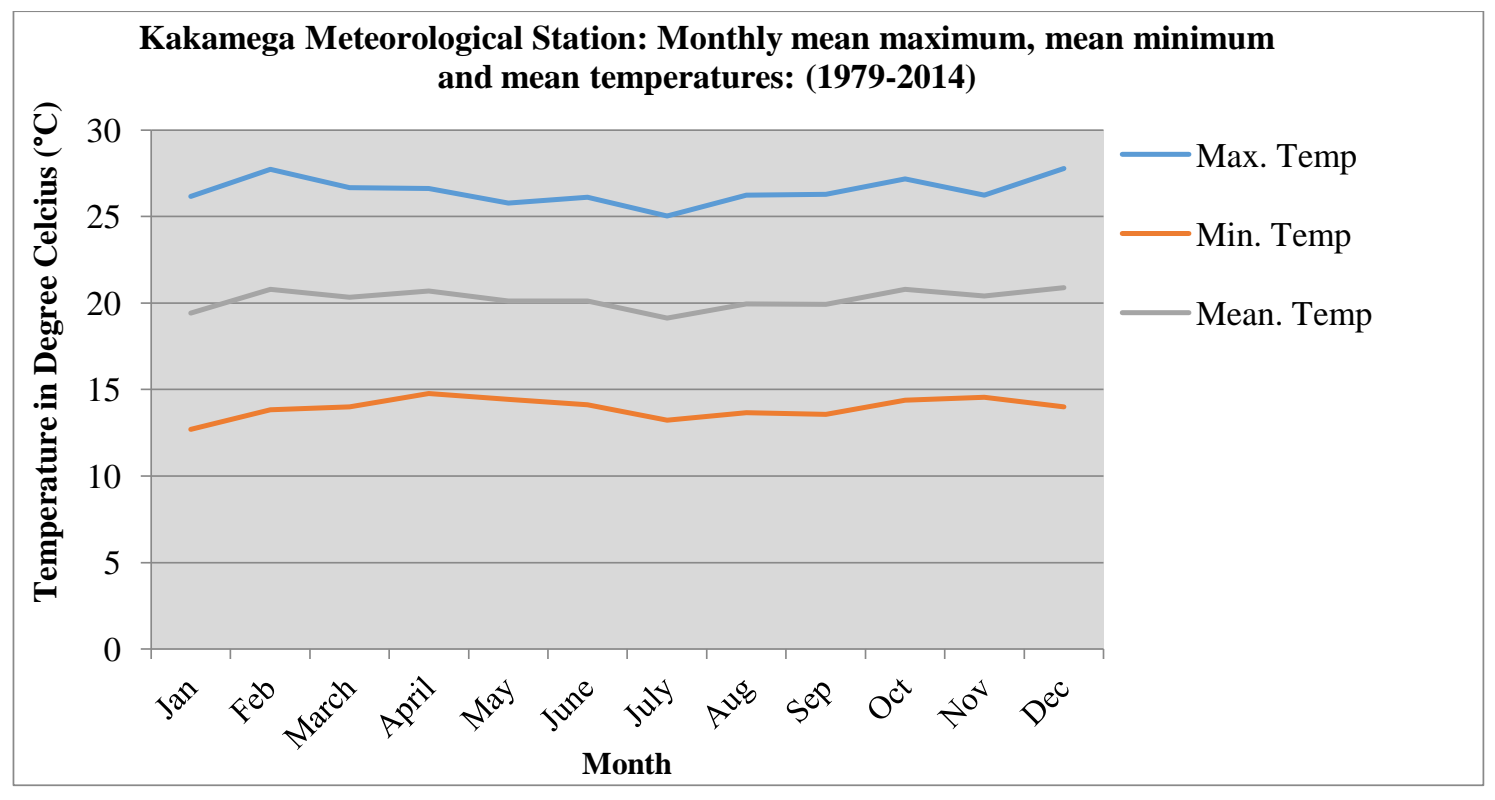

Fig. 4. Comparison of monthly mean minimum, mean maximum and mean temperatures for Kakamega meteorological station between 1979 and 2014 
The monthly mean minimum temperatures for Kakamega meteorological station in the period 1979 to 2014 depict a slowly declining trend from January to December. Beginning from January with $13.9^{\circ} \mathrm{C}$, the temperature rises to $15.1^{\circ} \mathrm{C}$ in April (highest temperature recorded in the year within the period) and then falls gradually to $13.57^{\circ} \mathrm{C}$ in September (lowest temperature recorded in the year within the period). The Annual mean minimum temperatures for Kakamega meteorological station depicts a rising trend from 1979 to 2014 at the rate of 0.000471

$\mathrm{C} /$ year. Lowest mean minimum temperatures in the period were recorded at $13.4{ }^{\circ} \mathrm{C}$ in 1990 and the highest temperature ever recorded in the period was at $15.0^{\circ} \mathrm{C}$ in 2010 . The monthly mean temperatures for Kakamega meteorological station in the period 1979 to 2014 depict a declining trend from January to December. Beginning from January with $21.3{ }^{\circ} \mathrm{C}$, the temperature rises to $22.0^{\circ} \mathrm{C}$ in March (highest temperature recorded in the year within the period) and then falls gradually to $19.7^{\circ} \mathrm{C}$ in July (lowest temperature recorded in the year within the period), followed by a gradual rise to $20.9^{\circ} \mathrm{C}$ in December to repeat the annual cycle. The Annual mean temperatures for Kakamega meteorological station depicts a rising trend from
1979 to 2014 at $0.000623^{0} \mathrm{C} /$ year. Lowest mean temperatures in the period were recorded at 20.1 ${ }^{0} \mathrm{C}$ in 1990 and the highest temperature ever recorded in the period was at $21.6{ }^{\circ} \mathrm{C}$ in 2005. The results in Fig. 4 shows that based on the standard seasons of December-JanuaryFebruary (DJF), March-April-May (MAM), JuneJuly August (JJA) and September- OctoberNovember (SON) in Nzoia River Basin, there has been fluctuations in monthly minimum, maximum and mean temperatures for the period between 1979 and 2014.

\subsection{Comparison of Monthly Maximum, Minimum and Mean Temperatures Across Nzoia River Basin for the Period 1979 to 2014}

The results in Figs. 5, 6 and 7 shows a comparison of monthly minimum, maximum and mean temperatures for Kitale, Kakamega and Eldoret international airport meteorological stations in the basin based on the standard seasons of December-January- February (DJF), March-April-May (MAM), June-July August (JJA) and September- October-November (SON). The results show that there has been temperature fluctuations all the year round.

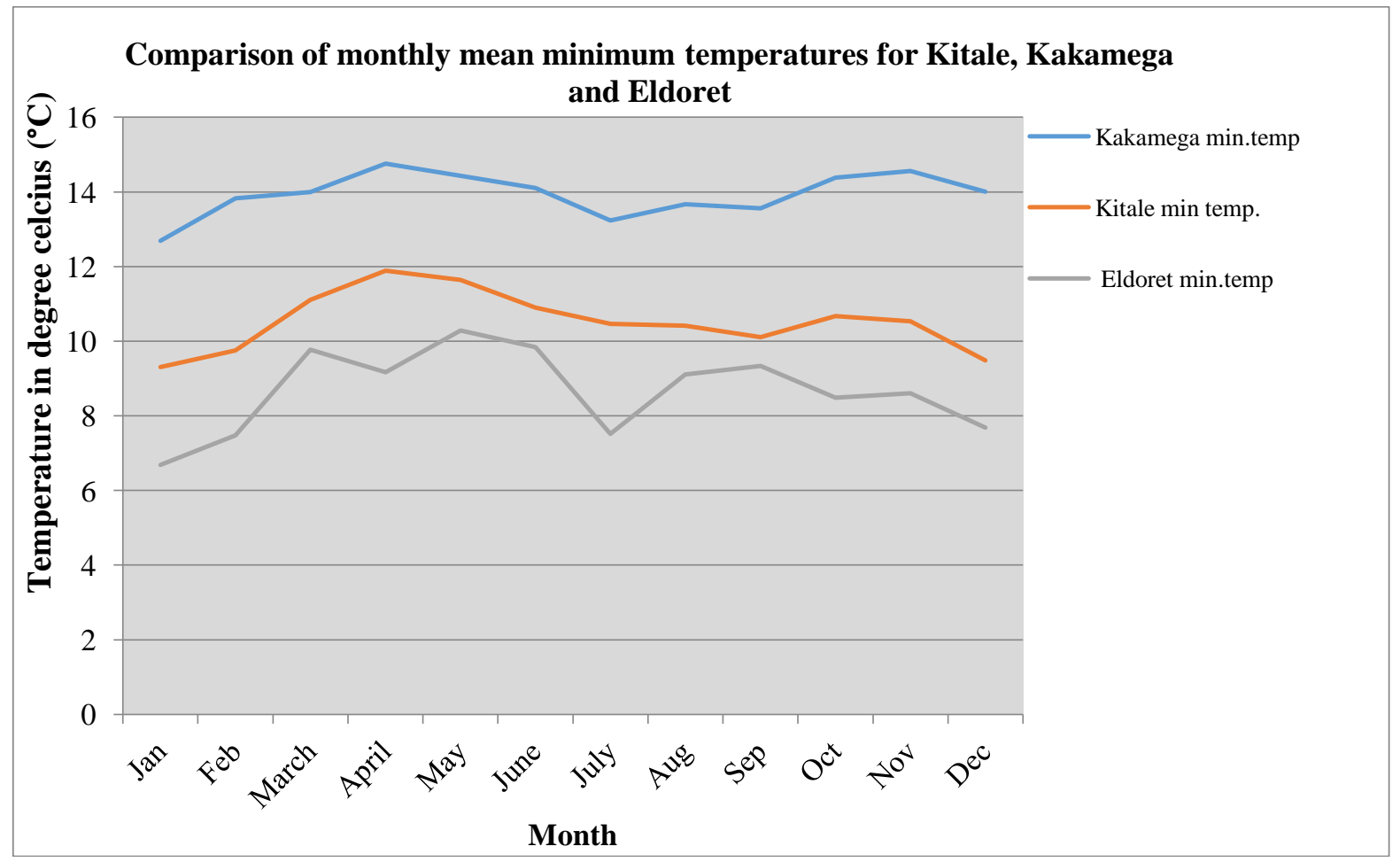

Fig. 5. Comparison of monthly minimum temperatures for Kitale, Kakamega and Eldoret international airport meteorological stations 


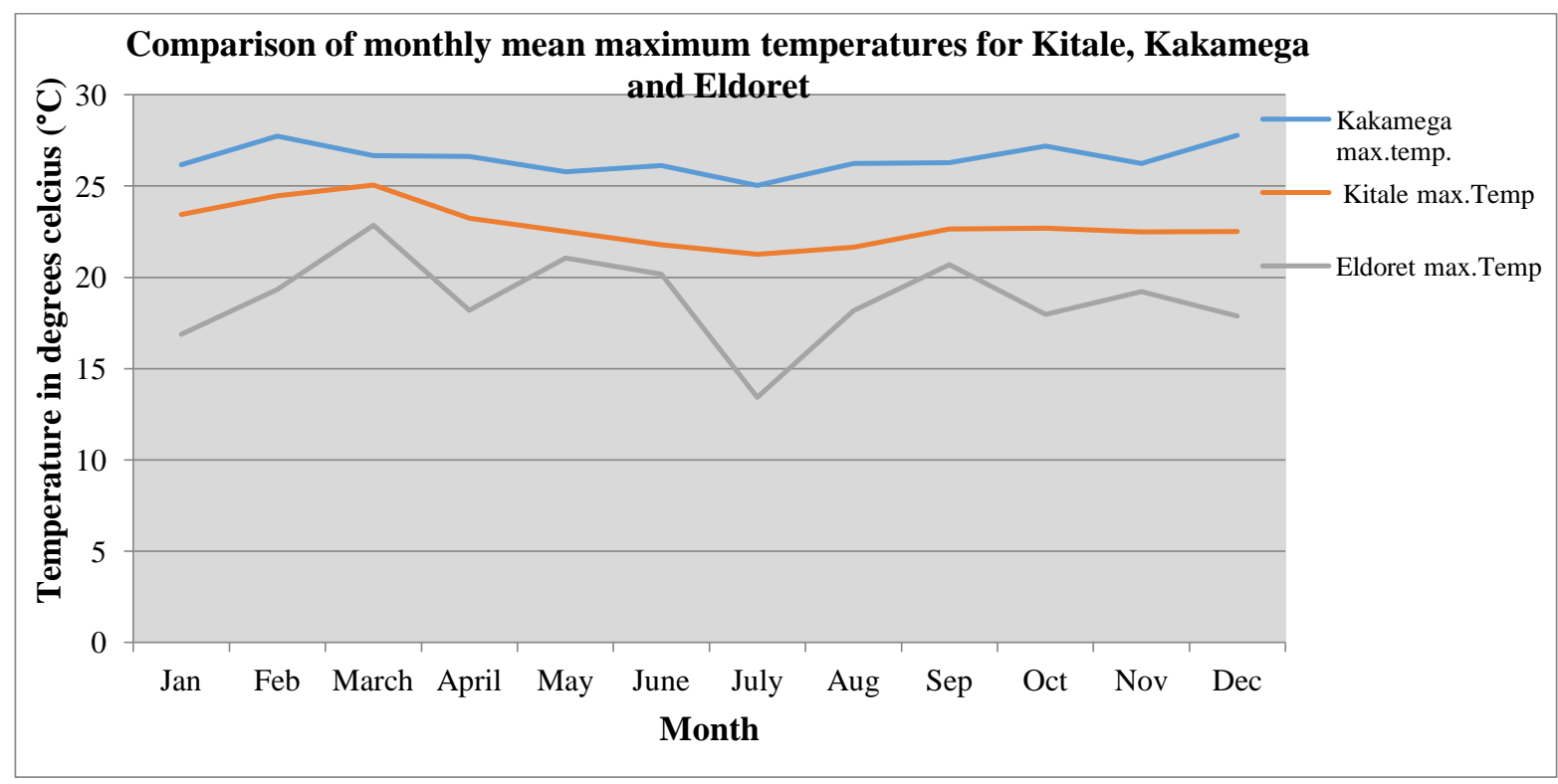

Fig. 6. Comparison of monthly maximum temperatures for Kitale, Kakamega and Eldoret international airport meteorological stations

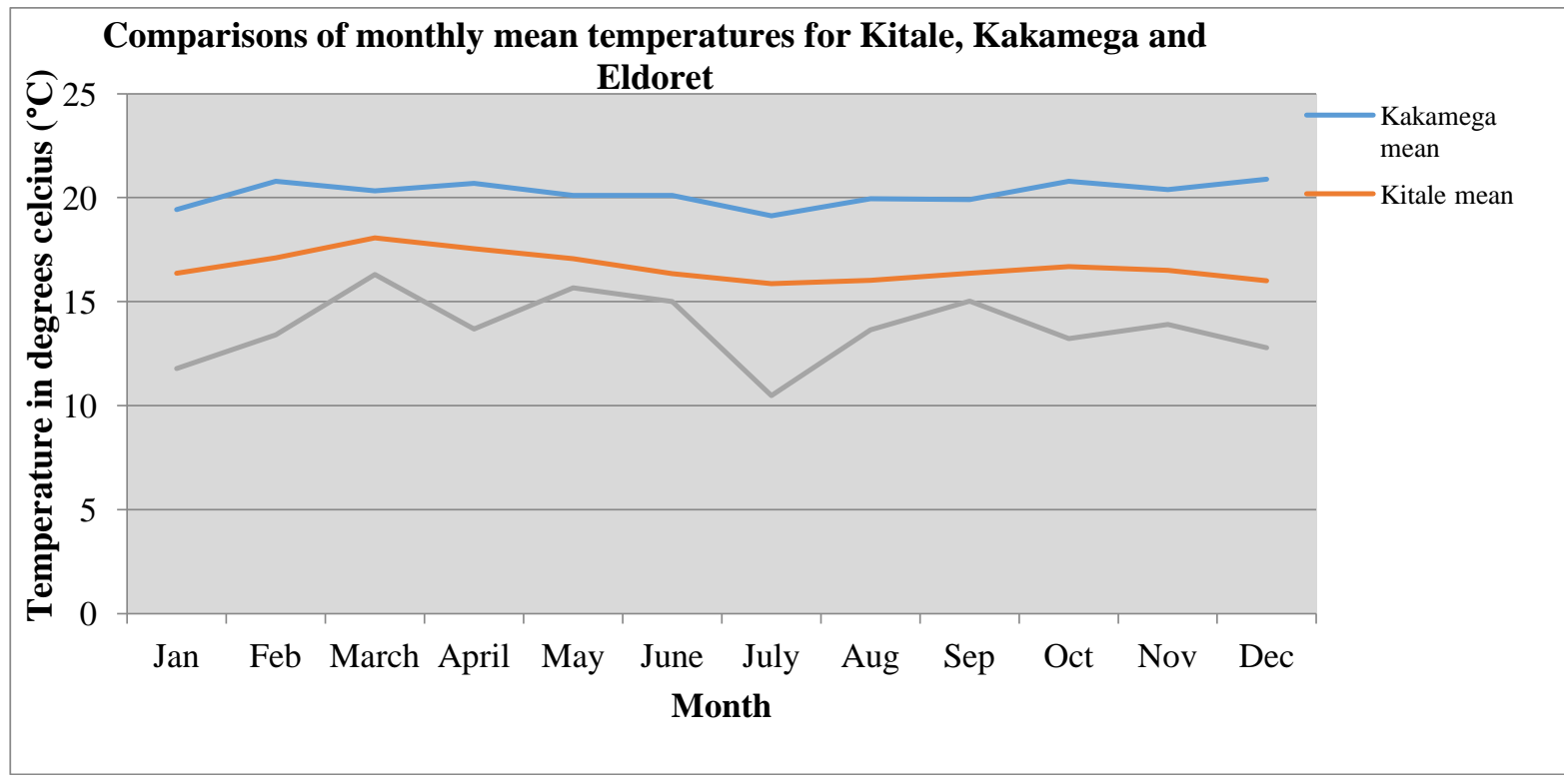

Fig. 7. Comparison of monthly mean temperatures for Kitale, Kakamega and Eldoret international airport meteorological stations

The temperature fluctuations also vary across Kitale, Kakamega and Eldoret international airport temperature stations. Kakamega has highest minimum temperatures, followed by Kitale and the lowest temperatures are found at Eldoret international airport meteorological station. The same partern still holds for both maximum and mean temperatures across the three stations. This trend seems to go with altitude since the lowest temperatures are found at highest altitudes and highest temperatures at lowest altitudes; the altitude of Kakamega is 1501 masl, Kitale, 1825 masl and Eldoret is 2120 masl.

\subsection{Maximum Temperature Trend in Nzoia River Basin}

The monthly mean maximum temperatures for the basin in the period 1979 to 2014 depict a declining trend from January to December. The lowest temperatures occur in the month of July 
with temperatures ranging between $16.1^{\circ} \mathrm{C}$ (Eldoret) to $25.8^{\circ} \mathrm{C}$ (Kakamega). Highest temperatures occur in the months of February and March with temperatures ranging between $18.4^{\circ} \mathrm{C}$ (Eldoret) to $29.5^{\circ} \mathrm{C}$ (Kakamega). The annual mean maximum temperatures for the basin depict both declining (Eldoret) and rising (Kitale and Kakamega) trends from 1979 to 2014. The lowest temperatures in the period were recorded in the year 2008 at $23.02^{\circ} \mathrm{C}$ (Eldoret) and the highest temperatures in the year 2009 at $28.3^{\circ} \mathrm{C}$ (Kakamega). In the basin, maximum temperatures at Kitale meteorological station has been rising at $0.0219^{\circ} \mathrm{C} / 35$ year $\left(0.000626^{\circ} \mathrm{C} /\right.$ year $)$. For Eldoret international airport, maximum temperatures has been falling at $-0.0303^{0} \mathrm{C} / 15$ year $\left(-0.00202^{0} \mathrm{C} /\right.$ year $)$. Kakamega meteorological station has had rising maximum temperatures at $0.027^{0} \mathrm{C} / 35$ year $\left(0.00077^{\circ} \mathrm{C} /\right.$ year $)$. Of the three stations, Kakamega has experienced the fastest rising annual maximum temperatures.

\subsection{Minimum Temperature Trend in Nzoia River Basin}

The monthly mean minimum temperatures for the basin in the period 1979 to 2014 depict both declining (Kitale and Kakamega) and rising (Eldoret) trends from January to December. The lowest temperatures occur in the months of January, July and September with temperatures ranging between $10.0^{\circ} \mathrm{C}$ (Eldoret) to $13.6^{\circ} \mathrm{C}$ (Kakamega). Highest temperatures occur in the month of April with temperatures ranging between $11.6^{\circ} \mathrm{C}$ (Eldoret) to $15.1^{\circ} \mathrm{C}$ (Kakamega). The annual mean minimum temperatures for the basin depict a rising trend from 1979 to 2014 . The lowest temperatures in the period were recorded in the year 2009 at $7.42^{\circ} \mathrm{C}$ (Eldoret) and the highest temperatures in the year 2010 at $15.0^{\circ} \mathrm{C}$ (Kakamega). In the basin, minimum temperatures at Kitale meteorological station has been rising at $0.0407^{\circ} \mathrm{C} / 35$ year $\left(0.001163^{\circ} \mathrm{C} /\right.$ year). For Eldoret international airport, minimum temperatures has been rising at $0.0122^{0} \mathrm{C} / 15$ year $\left(0.000813^{0} \mathrm{C} /\right.$ year). Kakamega meteorological station has had rising minimum temperatures at $0.0165^{\circ} \mathrm{C} / 35$ year $\left(0.000471^{\circ} \mathrm{C} /\right.$ year $)$. Of the three stations, Kakamega has experienced the fastest rising annual minimum tempratures.

\subsection{Mean Temperature Trend in Nzoia River Basin}

The monthly mean temperatures for the basin in the period 1979 to 2014 depicts a declining trend from January to December. The lowest temperatures occur in the month of July with tempratures ranging between $16.1^{\circ} \mathrm{C}$ (Eldoret) to $19.7^{\circ} \mathrm{C}$ (Kakamega). Highest temperatures occur in the month of March with temperatures ranging between $18.4^{\circ} \mathrm{C}$ (Eldoret) to $22.0^{\circ} \mathrm{C}$ (Kakamega). The annual mean temperatures for the basin depicts both falling (Eldoret) and rising (Kitale and Kakamega) trend from 1979 to 2014.

The lowest temperatures in the period were recorded in the year 1976 at $10.05^{\circ} \mathrm{C}$ (Kitale) and the highest temperatures in the year 2005 at $21.6^{\circ} \mathrm{C}$ (Kakamega). In the basin, mean temperatures at Kitale meteorological station has been rising at $0.0313^{\circ} \mathrm{C} / 35$ year

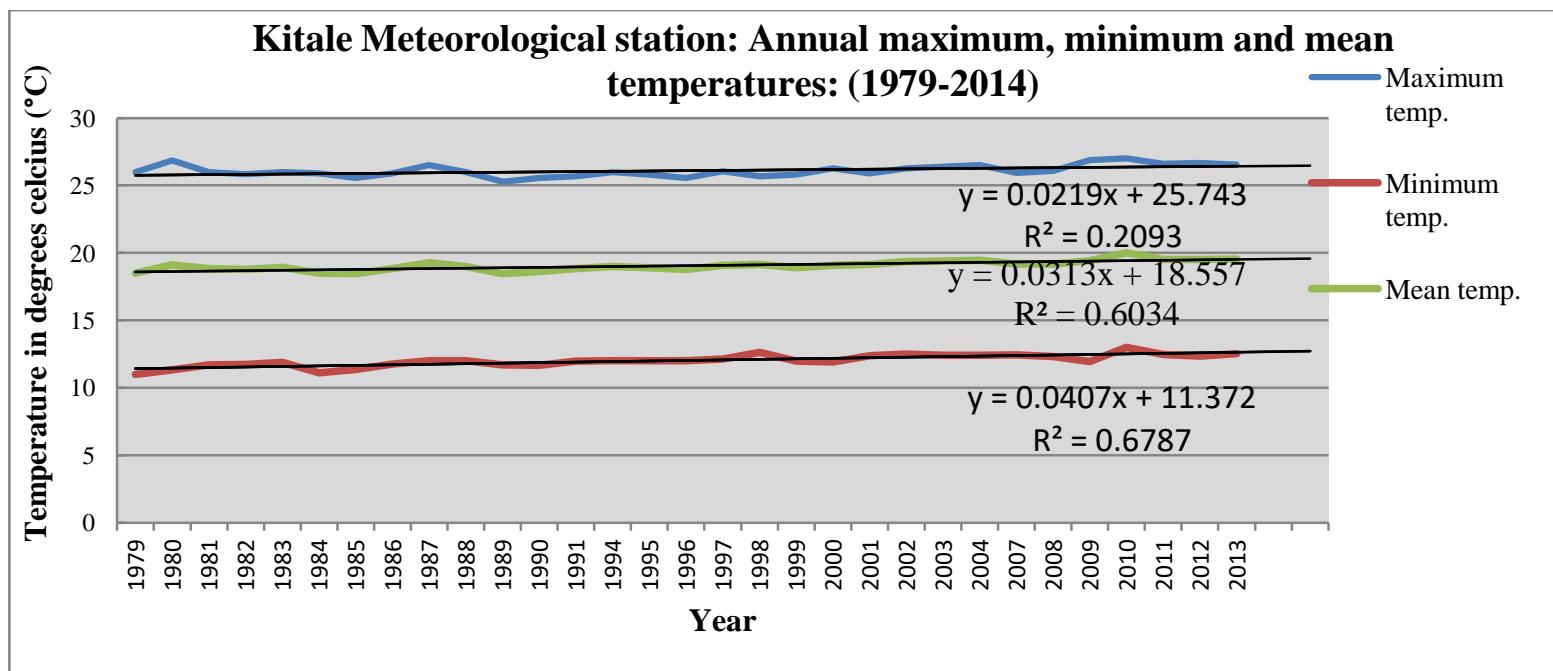

Fig. 8. Comparison of annual minimum, maximum and mean temperatures trends for Kitale meteorological station 
Table 2. Comparison of monthly and annual Kitale meteorological station temperature trends

\begin{tabular}{lllll}
\hline Temperature & $\begin{array}{l}\text { Monthly } \\
\text { trend }\end{array}$ & $\begin{array}{l}\text { Annual } \\
\text { trend }\end{array}$ & $\begin{array}{l}\text { Linear regression analysis results for annual } \\
\text { temperatures }\end{array}$ \\
\hline Maximum & Decreasing & Increasing & $0.000626{ }^{0} \mathrm{C} /$ year & $0.0626{ }^{0} \mathrm{C} / 100$ years \\
Minimum & Decreasing & Increasing & $0.001160^{\circ} \mathrm{C} /$ year & $1.163{ }^{0} \mathrm{C} / 100$ years \\
Mean & Decreasing & Increasing & $0.000894^{0} \mathrm{C} /$ year & $0.894{ }^{0} \mathrm{C} / 100 y e a r s$ \\
\hline
\end{tabular}

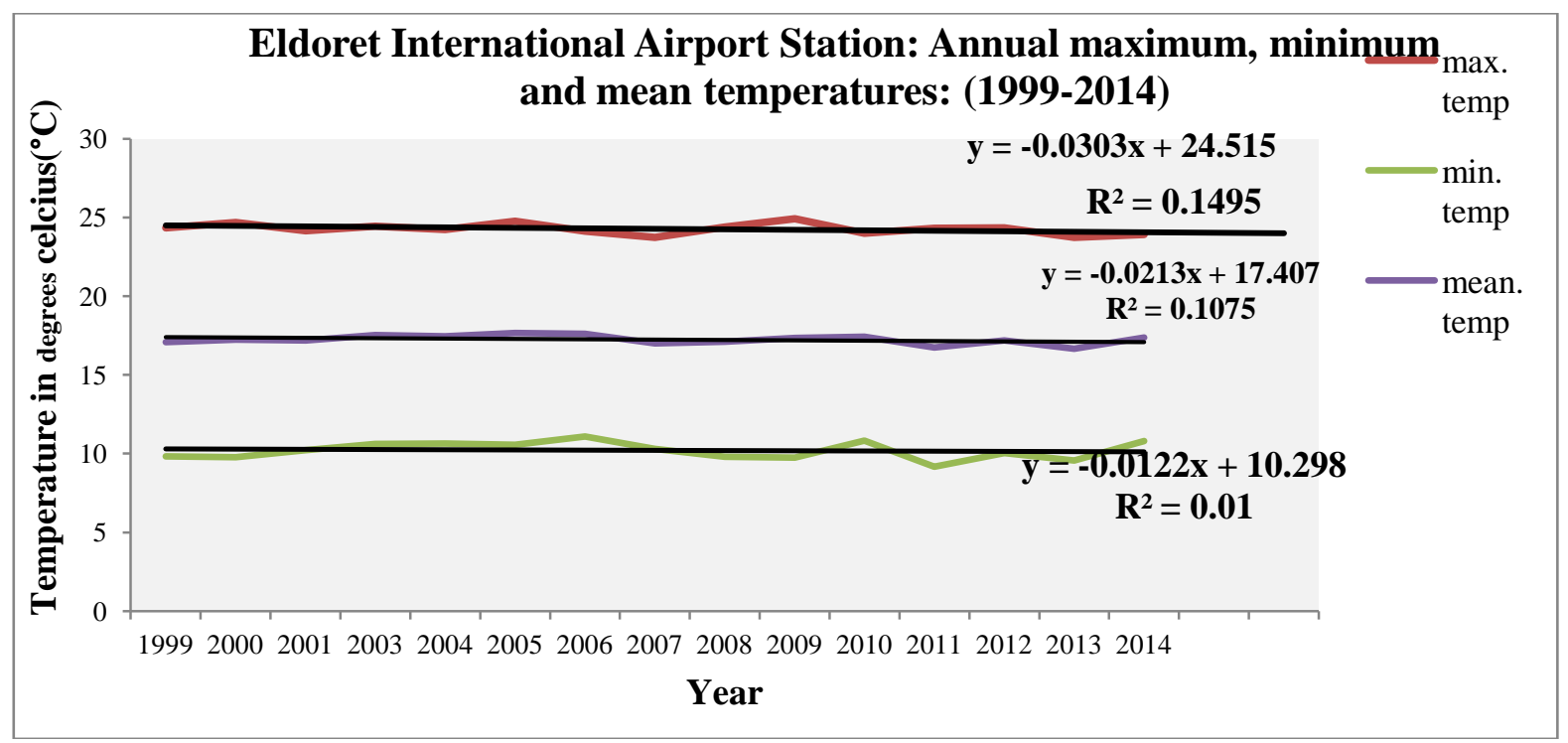

Fig. 9. Comparison of annual minimum, maximum and mean temperatures trends for Eldoret international airport

$\left(0.000894^{0} \mathrm{C} /\right.$ year). For Eldoret international airport, mean temperatures has been falling at $0.0213^{0} \mathrm{C} / 15$ year $\left(-0.00142^{0} \mathrm{C} /\right.$ year). Kakamega meteorological station has had rising mean temperatures at $0.0218^{0} \mathrm{C} / 35$ year $\left(0.000623^{0}\right.$ $\mathrm{C} /$ year). Of the three stations, Kitale has experienced the fastest rising annual mean temperatures. Linear regression analysis was used to analyse annual temperature trends for Kitale, Eldoret and Kakamega and the results are shown in Figs. 8, 9 and 10 respectively. There has been small fluctuations in annual minimum, maximum and mean temperatures for Kitale in the period between 1979 and 2014. Using a linear regression model, the rate of change is defined by the slope of regression line which in this case for Maximum temperature is $0.0219^{\circ}$ $\mathrm{C} / 35$ year $\left(0.000626{ }^{0} \mathrm{C} /\right.$ year). Similarly, for the minimum temperature, its $0.040{ }^{\circ} \mathrm{C} / 35$ year $\left(0.001163^{\circ} \mathrm{C} /\right.$ year $)$; and the mean temperature, $0.0313^{\circ} \mathrm{C} / 35$ year $\left(0.000894{ }^{\circ} \mathrm{C} /\right.$ year). Table 2 . shows a summary of monthly and annual temperature trends at Kitale meteorological station.

Fig. 9 shows a Comparison of the Annual Maximun, Minimum and Mean temperatures for
Eldoret international airport in the period 1999 to 2014. The Annual Maximun, Minimum and Mean temperature trend analysis are presented in this figure. There has been small fluctuations in annual minimum, maximum and mean temperatures in the period between 1999 and 2014. Using a linear regression model, the rate of change is defined by the slope of regression line which in this case for Maximum temperature is $-0.0303^{0} \mathrm{C} / 15$ year $\left(-0.00202^{0} \mathrm{C} /\right.$ year $)$. Similarly, for the minimum temperature, its $0.0122^{\circ} \mathrm{C} / 15$ year $\left(0.000813^{0} \mathrm{C} /\right.$ year $)$. For Eldoret international airport, the mean temperatures are falling at $-0.0213{ }^{0} \mathrm{C} / 15$ year ($0.00142{ }^{\circ} \mathrm{C}$ /year). Table. 3 shows a summary of monthly and annual temperature trends at Eldoret international airport meteorological station.

Fig. 10 shows a Comparison of the Annual Maximun, Minimum and Mean temperatures for Kakamega meteorological station in the period 1979 to 2014. The Annual Maximun, Minimum and Mean temperature trend analysis are presented in this figure. There has been small fluctuations in annual minimum, maximum and mean temperatures in the period between 1979 
and 2014. Using a linear regression model, the rate of change is defined by the slope of regression line which in this case for Maximum temperature is $0.027^{\circ} \mathrm{C} / 35$ year $\left(0.000771^{\circ}\right.$ $\mathrm{C} /$ year). Similarly, for the minimum temperature, its $0.0165^{\circ} \mathrm{C} / 35$ year $\left(0.000471^{0} \mathrm{C} /\right.$ year $)$. For the mean temperature, its $0.0218^{\circ} \mathrm{C} / 35$ year $\left(0.000623^{\circ} \mathrm{C} /\right.$ year). Table 4 shows a summary of monthly and annual temperature trends at Kakamega meteorological station.

Using a linear regression model, the rate of change is defined by the slope of regression line in each figure 8, 9 and 10 . Table 5 summarises the results. The annual temperature data for Kitale, Eldoret and Kakamega were analyzed for trend using Mann-Kenall test and the results are shown in Table 6.

\subsection{Mann- Kendall Test on Temperature}

The Mann Kendall technique, a non-parametric test, was performed to see if there is a monotonic upward or decreasing trend in temperature over time. In the research location, air temperature has a significant impact on the water cycle. When running the Mann-Kendall statistical test, if the $p$ value is less than the significance level $\alpha=0.05$, Ho, (there is no trend), hence, the hypothesis is not accepted. Rejecting $\mathrm{Ho}$ indicates that there is a trend in the time series, while accepting $\mathrm{Ho}$ indicates no trend is

Table 3. Comparison of monthly and annual eldoret international airport temperature trends

\begin{tabular}{lllll}
\hline Temperature & $\begin{array}{l}\text { Monthly } \\
\text { trend }\end{array}$ & Annual trend & \multicolumn{2}{l}{$\begin{array}{l}\text { Linear regression analysis results for annual } \\
\text { temperatures }\end{array}$} \\
\hline Maximum & Decreasing & Decreasing & $-0.00202{ }^{\circ} \mathrm{C} /$ year & $-0.202{ }^{\circ} \mathrm{C} / 100$ years \\
Minimum & Increasing & Increasing & $0.000813^{0} \mathrm{C} /$ year & $0.0813{ }^{0} \mathrm{C} / 100$ years \\
Mean & Decreasing & Decreasing & $-0.00142{ }^{\circ} \mathrm{C} /$ year & $-0.142{ }^{\circ} \mathrm{C} / 100$ years \\
\hline
\end{tabular}

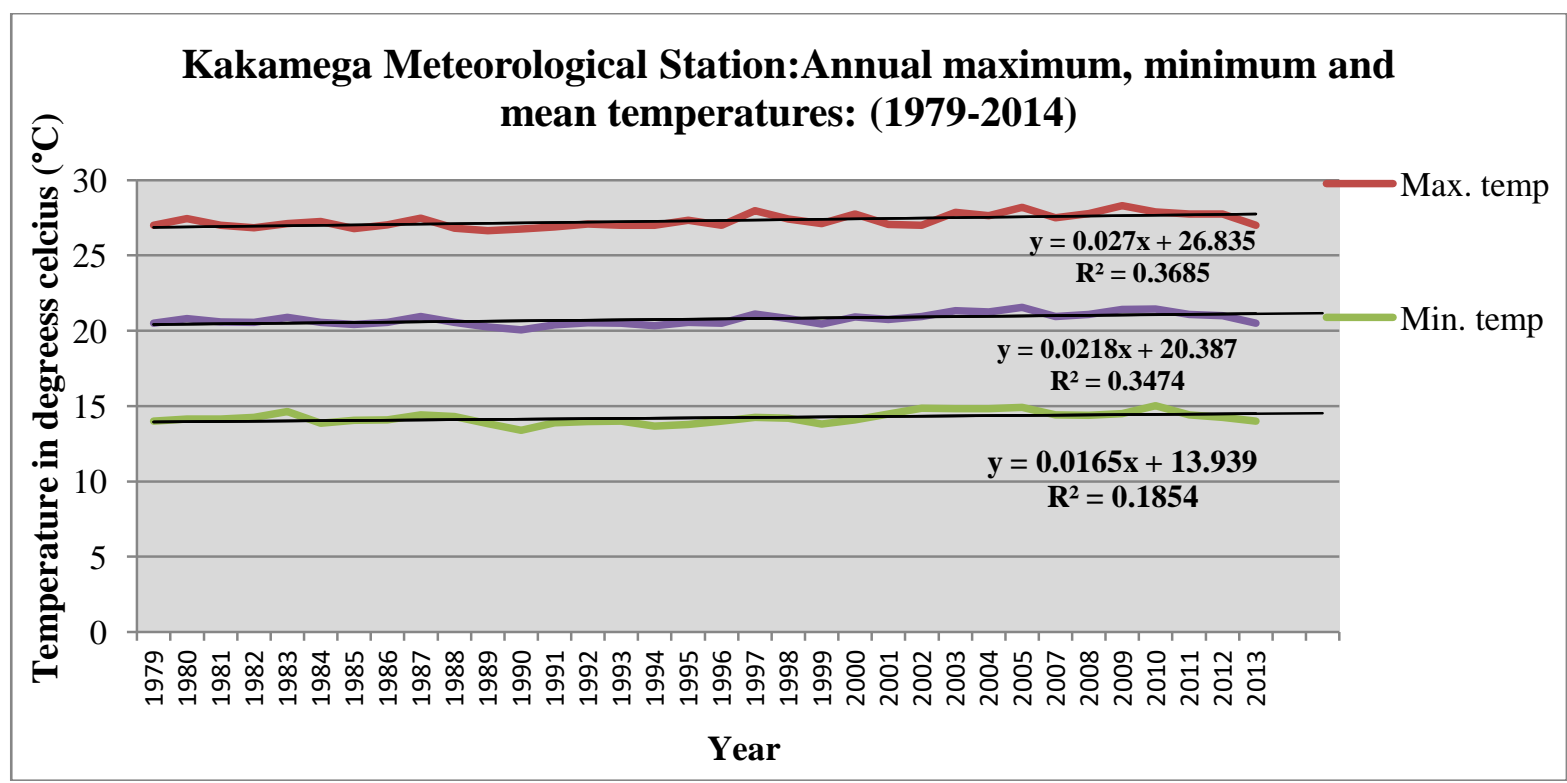

Fig. 10. Comparison of annual minimum, maximum and mean temperatures trends for Kakamega meteorological station

Table 4. Comparison of monthly and annual kakamega meteorological station temperature trends

\begin{tabular}{lllll}
\hline $\begin{array}{l}\text { Temperature } \\
\text { variables }\end{array}$ & $\begin{array}{l}\text { Monthly } \\
\text { trend }\end{array}$ & $\begin{array}{l}\text { Annual } \\
\text { trend }\end{array}$ & $\begin{array}{l}\text { Linear regression analysis results for annual } \\
\text { temperatures }\end{array}$ \\
\hline Maximum & Decreasing & Increasing & $0.000771^{\circ} \mathrm{C} /$ year & $0.0771{ }^{\circ} \mathrm{C} / 100$ years \\
Minimum & Decreasing & Increasing & $0.000471{ }^{\circ} \mathrm{C} /$ year & $0.0471{ }^{\circ} \mathrm{C} / 100$ years \\
Mean & Decreasing & Increasing & $0.000623^{\circ} \mathrm{C} /$ year & $0.0623^{\circ} \mathrm{C} / 100$ years \\
\hline
\end{tabular}


Table 5. Annual temperature trends in Nzoia River Basin, Kenya

\begin{tabular}{lllll}
\hline Station name & Annual Temperature & Slope & $\mathbf{R}^{2}$ & Trend \\
\hline Kitale Meterological & Maximum & 0.0219 & 0.2093 & Increasing \\
Station & Mean & 0.0313 & 0.6034 & Increasing \\
& Minimum & 0.0407 & 0.6787 & Increasing \\
\hline Eldoret International & Maximum & -0.0303 & 0.1495 & Decreasing \\
Airport & Mean & -0.0213 & 0.1075 & Decreasing \\
& Minimum & 0.0122 & 0.0100 & Increasing \\
\hline Kakamega & Maximum & 0.0270 & 0.3685 & Increasing \\
Meteorological Station & Mean & 0.0218 & 0.3474 & Increasing \\
& Minimum & 0.0165 & 0.1854 & Increasing \\
\hline
\end{tabular}

Table 6. Results of the mann-kendall test for annual mean temperature data for Nzoia River Basin, Kenya

\begin{tabular}{lllllll}
\hline $\begin{array}{l}\text { Station } \\
\text { name }\end{array}$ & $\begin{array}{l}\text { Mann } \\
\text { Kendall } \\
\text { Statistic (S) }\end{array}$ & $\begin{array}{l}\text { Kendall's } \\
\text { Tau }\end{array}$ & Var (S) & $\begin{array}{l}\text { Mann-Kalue (two } \\
\text { tailed test) }\end{array}$ & alpha & $\begin{array}{l}\text { Test } \\
\text { Interpretation }\end{array}$ \\
\hline $\begin{array}{l}\text { Kitale } \\
\begin{array}{l}\text { Meterologic } \\
\text { al Station }\end{array}\end{array}$ & 435.00 & 1 & 3141.66 & $<0.0001$ & 0.05 & $\begin{array}{l}\text { Reject Ho } \\
\text { Statistically } \\
\text { significant trend }\end{array}$ \\
\hline $\begin{array}{l}\text { Eldoret } \\
\text { International }\end{array}$ & -47.000 & -0.516 & 333.667 & 0.012 & 0.05 & $\begin{array}{l}\text { Reject Ho } \\
\text { Statistically } \\
\text { significant trend }\end{array}$ \\
\hline $\begin{array}{l}\text { Airport } \\
\text { Kakamega } \\
\text { Meteorologi } \\
\text { cal Station }\end{array}$ & 106.000 & 0.214 & 3800.66 & 0.089 & 0.05 & $\begin{array}{l}\text { Accept Ho } \\
\text { Statistically } \\
\text { insignificant trend }\end{array}$ \\
\hline
\end{tabular}

detected. Rejecting the null hypothesis implies that the result is said to be statistically significant at $\alpha=0.05$ level of significance ((Kitale and Eldoret international airport meteorological stations). For this test result, the null hypothesis is accepted for Kakamega meteorological station data.

In Kakamega meteorological station, annual temperature has shown no trend as the computed $p$-value is greater than the significance level $\alpha=0.05$ and the result is statistically insignificant.

Of the 3 stations, only 2 showed a statistically significant trend through the MK test at 5\% level of significance; and the trend for the remaining 1 station is statistically insignificant. Mann-Kendall test and linear regression test have been used to evaluate annual temperatures over Nzoia River Basin. Apart from this, the linear trend fitted to the data has also been tested with the Student ttest to verify results obtained by the MannKendall test and results are presented in Table 6. Table 7 shows a comparison of the results of Linear regression analysis and the Mann-Kendall test statistic (S) applied to the 3 temprature stations. Out of the 3 temperature stations, Mann Kendall test statistic (S) showed 2 stations recording increasing temperature similar to the linear fitted trend line. Both analysis methods also showed one station as recording decreasing temperature. Kitale and Kakamega meteorological stations recorded increasing tempratures whereas Eldoret international airport, recorded decreasing temperatures. The results for Kitale and Eldoret stations showed statistically significant trends whereas those for Kakamega station had a statistically insignificant trend. As one would expect, temperatures in Nzoia River Basin are expected to be rising; however, the case of decreasing temperatures recorded at Eldoret international airport might occur because this region of Rift valley has highly protected natural resources and a high forest cover is always present all the year round. Another possible explanation to this could be the changing cloudness around Eldoret station.

\subsection{Temperature Variability and Trends in Nzoia River Basin}

The variability and trends in annual and monthly temperature variables (maximum, minimum, and 
Table 7. Comparing linear trend fitted on data and mann-kendall test statistic (S) results for annual mean temperature data in Nzoia River Basin, Kenya

\begin{tabular}{|c|c|c|c|c|c|}
\hline \multirow[t]{2}{*}{ Station name } & \multicolumn{2}{|c|}{ Mann-Kendall test } & \multicolumn{2}{|c|}{ Fitted Linear trend line } & \multirow{2}{*}{$\begin{array}{l}\text { Mann Kendall } \\
\text { Test Statistical } \\
\text { Interpretation }\end{array}$} \\
\hline & $\begin{array}{l}\text { Mann } \\
\text { Kendall } \\
\text { Statistic (S) }\end{array}$ & $\begin{array}{l}\text { Temperature } \\
\text { trend }\end{array}$ & $\begin{array}{l}\text { Fitted } \\
\text { Linear trend } \\
\text { line slope }\end{array}$ & $\begin{array}{l}\text { Temperature } \\
\text { trend }\end{array}$ & \\
\hline $\begin{array}{l}\text { Kitale } \\
\text { Meterological } \\
\text { Station }\end{array}$ & 435.00 & Increasing & 0.0313 & Increasing & $\begin{array}{l}\text { Reject Ho } \\
\text { Statistically } \\
\text { significant trend }\end{array}$ \\
\hline $\begin{array}{l}\text { Eldoret } \\
\text { International } \\
\text { Airport }\end{array}$ & -47.000 & Decreasing & -0.0213 & Decreasing & $\begin{array}{l}\text { Reject Ho } \\
\text { Statistically } \\
\text { significant trend }\end{array}$ \\
\hline $\begin{array}{l}\text { Kakamega } \\
\text { Meteorological } \\
\text { Station }\end{array}$ & 106.000 & Increasing & 0.0210 & Increasing & $\begin{array}{l}\text { Accept Ho } \\
\text { Statistically } \\
\text { insignificant trend }\end{array}$ \\
\hline
\end{tabular}

mean temperatures) for three sites in Nzoia River Basin were investigated in this study. At Kitale and Eldoret stations, it was discovered that minimum temperatures are rising faster than maximum temperatures. These findings are consistent with those of Karl et al. [66], Qiang et al. [35], and Wibig and Glowicki [67], who found that minimum temperatures have risen at a significantly faster rate than maximum temperatures. Makokha and Shisanya [68] found that in Nairobi between 1966 and 1999, annual minimum temperatures were increasing faster than the annual maximum temperature. According to Skogseid [69] it was found that in Nairobi between 1980 and 2014, annual maximum temperatures rose at $0.4{ }^{0} \mathrm{C} / 34$ year ; minimum temperatures rose at.1.6 ${ }^{0} \mathrm{C} / 34$ year and mean temperatures rose at $1.0{ }^{\circ} \mathrm{C} / 34$ year, confirming that minimum temperatures were rising faster than maximum temperatures. Kakamega station on the other hand reported annual maximum temperatures that were rising faster than the minimum tempratures. This is exactly the opposite of Kitale and Eldoret stations. Rahman and Alam [70] studies in Bangladesh found maximum and minimum temperatures increasing at $5^{\circ} \mathrm{C}$ and $3^{\circ} \mathrm{C}$ per century, respectively.

In Nzoia River Basin, Kitale and Kakamega stations showed rising annual mean temperatures whereas Eldoret showed falling annual mean temperatures. As one would expect, temperatures in Nzoia River Basin are expected to be rising; however, the case of falling temperatures recorded at Eldoret international airport might occur because this region of Rift valley has highly protected natural resources and a high forest cover is present all the year round. Another explanation to the low temperatures recorded at Eldoret international airport could be due to changing cloudness. Ji and Zhou [39]; Tabari and Hosseinzadeh Talaee [40] found that the changing trends in air temperature were related to increased cloud cover and urbanization. Henderson-Sellers [71] also found that changes in cloudiness are closely related to differential increases in maximum and minimum temperatures. Darshana D. et.al [72] observes that "cloud cover is significantly negatively related with temperature variables in monsoon season and as a whole of the year; however, in summer season, positive correlation is found between cloud cover and temperature variables. Cloud cover affects the temperature due to the effect of cloud in reflecting and absorbing incoming visible solar radiation and outgoing infrared radiation. The effect of cloud on temperature depends on the balance of two competing effects; the cooling due to reduced solar radiation and the warming due to reduced outgoing long wave radiation. Cloud cover may have annual or seasonal effects on the temperature variables (mean, maximum and minimum)". In Eldoret, the average percentage of the sky covered by clouds experiences significant seasonal variation over the course of the year. The clearer part of the year in Eldoret begins towards the end of July and lasts for 3 months, ending around October. In September, the clearest month of the year, the sky is clear, mostly clear, or partly cloudy $46 \%$ of the time, and overcast or mostly cloudy $54 \%$ of the time. The cloudier part of the year begins in October and lasts for 9 months, ending around July. April has some of the cloudiest days of the year and the sky is overcast or mostly cloudy $82 \%$ of the time, and clear, mostly clear, or partly cloudy $18 \%$ of the time. The high cloud cover around 
Eldoret for most parts of the year could also account for the low temperatures recorded.

Kitale and Kakamega showed annual mean temperatures rising at about $0.1^{0} \mathrm{C}$ per century and Eldoret showed mean temperatures falling at about $-1.4{ }^{0} \mathrm{C}$ per century. The findings for Kitale and Kakamega stations compare well with IPCC Third Assessment Report estimated global warming rate of $0.6^{0} \mathrm{C}$ during the twentieth century [73]. The findings are also consistent with worldwide trends and studies from other parts of the world. The Austrian and Bavarian Alps [74,75], Swiss Alps [76-79], French Alps [80], Rocky Mountains in Colorado [81], and Southern Andes in Argentina and Chile, Villaba et al. [82] and Vuille et al. [83] have pinpointed out trends that are rising. According to Hulme et al. [41], Africa has warmed at a pace of around $0.5^{\circ} \mathrm{C}$ per century during the 1900s; and according to Hussein [43], Africa warmed by 0.7 degrees Celsius over the same time period. Funk [45] observes that Kenya has experienced a substantial warming during the last 50 years, and that Central Kenya witnessed significant increasing temperatures by $1^{\circ} \mathrm{C}$ in the months of March-June in the period 1960 to 2009. Just as for the case of Eldoret with falling annual mean temperatures; Jain and Kumar [84], observed that some stations in North and Northeast India showed falling trends in annual mean temperature data. Pant and Hingane [85], found decreasing trend in mean annual surface air temperature for 1901-1982 over the northwest Indian region consisting of the meteorological sub-divisions of Punjab, Haryana, west Rajasthan, east Rajasthan and west Madhya Pradesh.

\section{CONCLUSION}

This study has investigated air temperature variability and trends for 3 stations in Nzoia River Basin using Linear regression analysis and Mann-Kendall statistical test. Kitale and Kakamega stations showed rising annual mean temperatures whereas Eldoret showed falling annual mean temperatures. The results clearly indicate that changes are occurring in temperature within the basin and adverse impacts of climate change may worsen existing social and economic challenges faced by the County governments since most people are directly dependent on resources that are sensitive to climate change. Analysis of past and current budgetary investments and disaster interventions by County governments in the basin shows more focus on recovery from disasters rather than the creation of adaptive capacities to handle future situations. Increased capacity to manage future climate change and weather extremes may reduce the magnitude of economic, social and human suffering in the basin. National and County governments in the basin should design their development strategies and plans putting into account the observed temperature changes and the anticipated impacts on livelihoods. There is need for an integrated basinwide program on climate change detection, impact assessment, adaptation and mitigation measures.

\section{COMPETING INTERESTS}

Author has declared that no competing interests exist.

\section{REFERENCES}

1. Thapliyal V, Kulshrestha SM. Decadal changes and trends over India.Mausam 1991;42:333-338.

2. Jones PD, Horton EB, Folland CK, Hulme $M$, Parker DE, Basnett TA. The Use of Indices to Identify Changes in Climatic Extremes, Climatic Change. 1999;42(1):131-149.

3. IPCC. Climate Change : Impacts, Adaptation and Vulnerability, In: J. McCarthy, O. Canziani, N. Leary, D.Dokken and K. White, Eds., Contribution of Working Group II to the Third Assessment Report of the (IPCC), World Meteorological Organisation and United Nations Environment Programme, Cambridge University Press, Cambridge; 2001.

4. Karl TR, Easterling DR. Climate extremes: Selected review and future research directions, Clim. Change. 1999;42:309325.

5. Robeson SM. Trends in time-varying percentiles of daily minimum and maximum temperature over North America, Geophys. Res. Lett. 2004;31.

6. Bonsal BR, Zhang X, Vincent LA, Hogg WD. Characteristics of daily and extreme temperatures over Canada, J. Clim. 2001;14:1959-1976.

7. Klein Tank, AMG, Konnen GP. Trends in indices of daily temperature and precipitation extremes in Europe, J. Clim. 2003;15:3665-3680. 
8. Plummer $\mathrm{N}$, Salinger MJ, Nicholls $\mathrm{N}$, Suppiah R, Hennessy KJ, Leighton RM, et al. Changes in climate extremes over the Australian region and New Zealand during the twentieth century, Clim. Change. 1999;42:183-202.

9. King'uyu SM, Ogallo LA, Anyamba EK. Recent trends of minimum and maximum surface temperatures over eastern Africa, J. Clim. 2000;13:2876-2886.

10. Roy SS, Balling Jr RC. Analysis of trends in maximum and minimum temperature, diurnal temperature range, and cloud cover over India, Geophys. Res. Lett. 2005;32.

11. Ryoo SB, Kwon WT, Jhun JG. Characteristics of wintertime daily and extreme minimum temperature over South Korea, Int. J. Climatol. 2004;24:145-160.

12. Beniston M, Diaz HF, Bradley RS. Climate change at high elevation sites: An overview, Clim. Change. 1997;36 :233251.

13. Diaz HF, Grosjean M, Graumlich L. Climate variability and changes in high elevation regions: Past, present and future, Clim. Change. 2003;59:1-4.

14. Messerli B, Ives JD. (Eds.). Mountains of the World: A Global Priority, Parthenon, New York; 1997.

15. Weber RO, Talkner $\mathrm{P}$, Auer L, Bohm R, Gajic-Capka M, Zaninovic K, et al. 20th century changes of temperatures in the mountain regions of Central Europe, Clim. Change. 1997;36:327-344.

16. Nicholls $\mathrm{N}$, Collins D. Observed change in Australia over the past century. Energy Environ. 2006;17:1-12.

17. Luterbacher J, Dietrich D, Xoplaki E, Grosjean M, Wanner $H$. European seasonal and annual temperature variability. Trends Extremes Sci. 2004;303 (5663):1499-1503.

18. Vincent LA, Wijngaarden WAV, Hopkinson R. Surface temperature and humidity trends in Canada for 1953-2005. J. Climate. 2007;20:5100-5113.

19. IPCC. Impacts, Adaptation and Vulnerability. Contribution of Working Group II. In: Parry ML, Canziani OF, Palutikof JP, van der Linden PJ, Hanson CE. (Eds.), Fourth Assessment Report of the Intergovernmental Panel on Climate Change. Cambridge University Press, Cambridge, UK. 2007;541-580.
20. Peterson BJ, Holmes RM, McClelland JW, Vorosmarty CJ, Lammers R, Shiklomanov $\mathrm{Al}$, et al. Increasing river discharge to the Arctic Ocean. Science. 2005;298:137143.

21. Batima P, Natsagdorj L, Gombluudev P, Erdenetsetseg B. Observed climate change in Mongolia. AIACC Working Paper. 2005;13:25.

22. Shi YF, Shen YP, Hu RJ. Preliminary study on signal, impact and foreground of climatic shift from warm-dry to warm-humid in Northwest China. J. Glaciol. Geocryol. 2002;24:219-226.

23. Ichikawa A. (Ed.). Global warming. The Research Challenges: A Report of Japan's Global Warming Initiative. Springer, Berlin; 2004.

24. Jung HS, Choi Y, Oh JH, Lim GH. Recent trends in temperature and precipitation over South Korea. Int. J. Climatol. 2002;22:1327-1337.

25. Cruz RVO, Lasco RD, Pulhin JM, Pulhin FB, Garcia KB. Climate change impact on water resources in Pantabangan Watershed, Philippines. AIACC Final Technical Report. 2006;9-107.

26. Arora M, Goel NK, Singh P. Evaluation of temperature trends over India. Hydrol. Sci. J. 2005;50(1):81-93.

27. Dash SK, Jenamani RK, Kalsi SR, Panda SK. Some evidence of climate change in twentieth-century India. Clim. Change. 2007;85:299-321.

28. Kothawale DR, Rupa Kumar K. On the recent changes in surface temperature trends over India. Geophys. Res. Lett. 2005;32.

29. Pant GB, Kumar KR. Climates of South Asia. John Wiley \& Sons Ltd, Chichester, UK; 1997.

30. Sinha Ray KC, De US. Climate change in India as evidenced from instrumental records. WMO Bull. 2003;52(1):53-59.

31. Dhorde A, Dhorde A, Gadgil AS. Long-term temperature trends at four largest cities of India during the twentieth century. J. Indian Geophys. Union. 2009;13(2):85-97.

32. Gadgil A, Dhorde A. Temperature trends in twentieth century at Pune, India. Atmos. Environ. 2005;39:6550-6556.

33. De US, Mukhopadhyay RK. Severe heat wave over the Indian subcontinent in 1998, in perspective of global climate. Curr. Sci. 1998;75:1308-1311. 
34. Easterling DR, Horton $B$, Jones $P D$, Peterson TC, Karl TR, Parker DE, et al. Maximum and minimum temperature trends for the globe. Science. 1997;227: 364-365.

35. Qiang F, Celeste MJ, Stephen GW, Dian JS. Contribution of stratospheric cooling to satellite inferred tropospheric temperature trends. Nature. 2004;429:55-57.

36. Soltani E, Soltani A. Climatic change of Khorasan, North-East of Iran, during 19502004. Res. J. Environ. Sci. 2008;2(5):316322.

37. Cohen S, Stahill G. Contemporary climate change in the Jordan valley. J. Appl. Meteorol. 1996;35:1051-1058.

38. Ramanathan V, Feng Y. Air pollution, greenhouse gases and climate change: global and regional perspectives. Atmos. Environ. 2009;43:37-50.

39. Ji Y, Zhou G. Important factors governing the incompatible trends of annual pan evaporation: evidence from a small scale region. Clim. Change. 2011;106:303-314.

40. Tabari H, Hosseinzadeh Talaee P. Recent trends of mean maximum and minimum air temperatures in the western half of Iran. Meteorol. Atmos. Phys. 2011;111 :121131.

41. Hulme M, Doherty R, Ngara T, New M, Lister D. African climate change: 19002100. Climate Research. 2001;17:145-168.

42. Niang I, Ruppel OC, Abdrabo MA, Essel A, Lennard C, Padgham J, Urquhart P.. Africa. In: Climate Change 2014: Impacts, Adaptation, and Vulnerability. Part B: Regional Aspects. Contribution of Working Group II to the Fifth Assessment Report of the Intergovernmental Panel on Climate Change. Cambridge, United Kingdom and New York, NY, USA: Cambridge University Press; 2014.

43. Hussein MA. Climate Change Impacts on East Africa. In The Economic, Social and Political Elements of Climate Change, ed. W. Leal Filho, 589-601. Climate Change Management series. New York and Heidelberg: Springer; 2011.

44. Anyah RO, Qiu W. Characteristic 20th and 21st century precipitation and temperature patterns and changes over the Greater Horn of Africa. International Journal of Climatology. 2012;32:347-363.

45. Funk C. A climate trend analysis of Kenya, August (2010). U. S. Geological Survey:
Reston, VA, United States, Report 23276916, United States; 2010.

46. Kumar V, Jain SK, Singh Y. Analysis of long term rainfall trends in India. Hydrological Sciences Journal. 2010;55(4) :484-496.

47. Odwori EO, Wakhungu JW. Rainfall variability and trends over Nzoia River Basin, Kenya. Journal of Engineering Research and Reports. 2021;21(4);26-52.

48. Odwori EO, Munyendo LLW. Impact of Covid-19 crisis on drinking water utilities in Nzoia River Basin, Kenya. African Journal of Social Sciences and Humanities Research. 2020;3(6):204-215.

49. Roman R, Bilbao J, De Miguel A. Reconstruction of six decades of daily total solar shortwave irradiation in the Iberian Peninsula using sunshine duration records. Atmos. Environ. 2014;99:41-50.

50. El Kenawy A, Lopez-Moreno Jl, Stepanekc $P$, Vicente-Serrano SM. An assessment of the role of homogenization protocol in the performance of daily temperature series and trends: Application to northeastern Spain. Int. J. Climatol. 2013;33:87-108.

51. Bilbao J, De Miguel A, Ayuso A, Franco,JA. Iso-radiation maps for tilted surfaces in the Castile and Leon region, Spain. Energy Convers. Manag. 2003;44:1575-1588.

52. Miguel A, Bilbao J, Román R, Mateos D. Measurements and attenuation of erythemal radiation in Central Spain. Int. J. Climatol. 2003;32,-940.

53. Gocic M, Trajkovic S. Analysis of changes in meteorological variables using MannKendall and Sen's slope estimator statistical tests in Serbia. Glob. Planet. Chang. 2013;100:172-182.

54. Kundzewicz ZW. Change detection in hydrological records - a review of the methodology. Hydrol. Sci., J. 2004;49(1):7-19.

55. Sen PK. Estimates of the regression coefficient based on Kendall's tau. J. Am. Stat. Assoc. 1968;63:1379-1389.

56. Fan JQ, Yao QW. Nonlinear Time Series: Nonparametric and Parametric Methods (Springer Series in Statistics). SpringerVerlag, New York; 2003.

57. Sneyers R. On the Statistical Analysis of Series of Observations; WMO Technical Note 143, WMO No. 415, TP-103; World Meteorological Organization: Geneva, Switzerland; 1990. 
58. Gilbert RO. Statistical Methods for Environmental Pollution Monitoring; Van Nostrand Company: Hoboken, NJ, USA; 1987.

59. Sayemuzzaman M, Mekonnena A, Jha MK. Diurnal temperature range trend over North Carolina and the associated mechanisms. Atmos. Res. 2015;160 :99108.

60. Espadafor M, Lorite IJ, Gavilán P, Berengena J. An analysis of the tendency of reference evapotranspiration estimates and other climate variables during the last 45 years in Southern Spain. Agric. Water Manag. 2011;98:1045-1061.

61. Mann HB. Non-Parametric Tests against Trend. Econometrica, 1945;13:245-259.

62. Kendall MG. Rank Correlation Measures. Charles Griffin, London; 1975.

63. Del Rio S, Cano-Ortiz A, Herrero L, Penas A. Recent trends in mean maximum and minimum air temperatures over Spain (1961-2006). Theor. Appl. Climatol. 2012;109:605-626.

64. Sayemuzzaman M, Jha MK, Mekonnen A, Schimmel, K.A. Subseasonal climate variability for North Carolina, United States. Atmos. Res. 2014;145:69-79.

65. Keredin TS, Annisa M, Surendra B, Solomon A. Long years comparative climate change trend analysis in terms of temperature, coastal Andhra Pradesh, India. Refer J Res Sci Technol. 2013;2(7). ISSN 2277-1174.

66. Karl TR, Jones PD, Knight RW, Kukla G, Plummer N, Razuvayev V, et al. A new perspective on recent global warming: Asymmetric trends of daily maximum and minimum temperature. Bull. Am. Meteorol. Soc. 1993;74:1007-1023.

67. Wibig J, Glowicki B. Trends in minimum and maximum temperature in Poland. Clim. Res. 2002;20:123-133.

68. Makokha GL, Shisanya CA. Trends in Mean Annual Minimum and Maximum Near Surface Temperature in Nairobi City, Kenya. Advances in Meteorology. 2010; 6.

69. Skogseid MW. Climate Change in Kenya A review of literature and evaluation of temperature and precipitation data, Nairobi, Kenya; 2017.

70. Rahman A, Alam M. Mainstreaming Adaptation to Climate Change in Least Developed Countries (LDCs). Working
Paper 2: Bangladesh Country Case Study, IIED, London; 2003.

71. Henderson-Sellers, A. Future climates of the world: a modeling perspective. World Surv. Climatol. 1995;16:1-608.

72. Darshana D, Ashish P, Krishan PSGRPP. Spatial and temporal variability in maximum, minimum and mean air temperatures at Madhya Pradesh in central India. C. Geoscience; 2013.

73. Houghton JT, Ding Y, Griggs DJ, Noguer $M$, van der Linden PJ, Dai X, et al. Climate Change (2001): The Scientific Basis, Cambridge Univ. Press, New York; 2001.

74. Auer I, Boehm R. Combined temperatureprecipitation variations in Austria during the instrumental record. Theor Appl Climatol. 1994;49:161-174.

75. Diaz HF, Bradley RS. Temperature variations during the last century at high elevation sites. Clim Change. 1997;36:253-279.

76. Beniston M. Mountain environments in changing climates. Routledge, London; 1994.

77. Beniston M. Variation of snow depth and duration in the Swiss Alps over the last 50 years: links to changes in large-scale climatic forcings. Clim Change. 1997;36:281-300.

78. Beniston M. Climatic change in mountainous regions: A review of possible impacts. Clim Change. 2003;59:5-31.

79. Rebetez M. Summer 2003 maximum and minimum daily temperature over a 3,300 m altitudinal range in the Alps. Clim Res. 2004;27:45-50.

80. Jamelli V, Pech VP, Chochillan C, Brunstein, D. Geomorphic variability of debris flows and recent climate changes in the French Alps. Clim Change. 2004;64:77-102.

81. Brown TB, Barry RG, Doesken NJ. An exploratory study of temperature trends for Colorado paired mountain-high plains stat ions. American Meteorological Society sixth conference on mountain meteorology, Portland; 1992.

82. Villaba $R$, Lara A, Boninsegna JA, Masiokas M, Delgado S, Aravena JC, Roig FA, Schmelter A, Wolodarsky A, Ripalta A. Large-scale temporal changes across the southern Andes: 20th century variations in the context of the past 400 years. Clim Change. 2003;59:177-232. 
83. Vuille M, Bradley RS, Werner M, Keimig F. 20th century climate change in the tropical Andes: observations and model results. Clim Change. 2003;59:75-99.

84. Jain S. K. and Kumar V. Trend analysis of rainfall and temperature data for India. Current Sci. 2012;102(1):37-49. 9.

85. Pant GB, Hingane LS. Climatic changes in and around the Rajasthan desert during the 20th century. Int. J. Climatol. 1988;8: 391-401.

(C) 2021 Odwori; This is an Open Access article distributed under the terms of the Creative Commons Attribution License (http://creativecommons.org/licenses/by/4.0), which permits unrestricted use, distribution, and reproduction in any medium, provided the original work is properly cited.

Peer-review history:

The peer review history for this paper can be accessed here:

https://www.sdiarticle5.com/review-history/77403 